\title{
Sûrebaşı Tezhiplerinde Desen Çeşitliliğini Sağlayan Unsurların Alanya Müzesi 487 Envanter Numaralı Kur’an-ı Kerîm Örneğinde İncelenmesi*
}

\author{
Investigation of the Components of Patterns Providing Diversity in the Qur'an \\ Numbered 487 in the Alanya Museum Inventory
}

\author{
Ummuhan Kaçar** ${ }^{*}$, Muhammet Bilgen ${ }^{* * *}$ (1)
}

Öz

Müze ve kütüphanelerde korunan yazma eserler arasında nüsha sayısı bakımından Kur'an-ı Kerimler ilk sıralarda yer almaktadır. Tezyin edilmiş Kur’an-ı Kerim nüshaları koleksiyonların nadide eserlerini oluşturmaktadır. Mushaf tezyinat geleneğinde karşımıza çıkan alanlardan birisi de sûrebaşı (başlık, unvan) tezhipleridir. Kur'an-ı Kerim'de mevcut yüz on dört adet sûrenin yüz on ikisinde (Fatiha ve Bakara sûresi hariç), yer alan sûrebaşı tezhiplerinde kullanılan desen sayısı, esere göre değişiklik göstermektedir. Nakkaşhanede, sanat merkezlerinde veya zengin kitap hamilerinin desteğiyle hazırlanan eserlerde tezyinat yoğunluğu ve desen çeşitliliği artmaktadır. Desenlerde görülen motiflerin; formu, büyüklüğü, sıklığı, çeşitleri, denge, espas vb. unsurlar üslupların karakteristik özelliklerini yansıtırlar. Bu özellikler, istinsah tarihi belli olmayan yazma eserlerin dönem tahmininde yararlanılan kıstaslardandır. Yazma eserlerin, yapılan bilimsel araştırmalarla yazılı olarak kayıt altına alınması ve gelecek nesillere aktarılması önem arzetmektedir. Bu nedenle yapılan çalışmada klasik üslupta hazırlanmış ve istinsah tarihi belli olmayan Konya Yazma Eserler Bölge Müdürlüğü’nde korunan Alanya Müzesi 487 Envanter Numaralı Kur'an-ı Kerîm kapsamında, sûrebaşı tezhiplerinde görülen desen çeşitliliğini sağlayan unsurlar üzerinde durularak, kullanılan kompozisyon, biçim, teknik ve motif özellikleri sistematik bir yol izlenerek değerlendirilmiştir.

\section{Anahtar Kelimeler}

Kur’an-I Kerîm, Tezhip, Desen, Yazma Eser, Klasik Dönem

\begin{abstract}
Among manuscripts preserved in museums and libraries in Turkey, the Qur'an has the most number of copies. Copies of decorated Qur'ans constitute the most precious pieces of the any collection. One of the fields in the Qur'an gilding tradition is Sûrebaşı Gildings (a gilding adorning the top of the Surahs in the Qur'an). The pattern quantity of Sûrebaşı Gildings present in 112 of the 114 existing surahs (except surah al-Fatihah and surah al-Baqarah) in the Qur'an shows
\end{abstract}

* Bu makale Kastamonu Üniversitesi Sosyal Bilimler Enstitüsü Sanat ve Tasarım Anasanat Dalı’nda Dr. Öğr. Üyesi Muhammet Bilgen'in danışmanlığında, Ummuhan Kaçar tarafindan hazırlanmış olan “Konya Yazma Eserler Bölge Müdürlüğü’nde Korunan Alanya Müzesi 487 Envanter Numaralı Kur’an-ı Kerîm'in Tezhiplerinin İncelenmesi” başlıkl yüksek lisans tezinden faydalanılarak oluşturulmuştur.

** Sorumlu Yazar: Ummuhan Kaçar (Yüksek Lisans mezunu), İstanbul, Türkiye. E-posta: ummuhankacar@gmail.com, ORCID: 0000-0002-7746-3869

*** Muhammet Bilgen (Dr. Öğr. Üyesi), Kastamonu Üniversitesi, Güzel Sanatlar ve Tasarım Fakültesi, Geleneksel Türk Sanatları Bölümü, Kastamonu, Türkiye. E-posta: mbilgen99@gmail.com, ORCID: 0000-0002-9132-3950

Atıf: Kacar, Ummuhan ve Bilgen, Muhammet. "Sûrebaşı Tezhiplerinde Desen Çeşitliliğini Sağlayan Unsurların Alanya Müzesi 487 Envanter Numaralı Kur’an-ı Kerîm Örneğinde İncelenmesi." Art-Sanat, 16(2021): 329-354 https://doi.org/10.26650/artsanat.2021.16.0011 
an alteration depending on the individual piece. In the pieces prepared in arthouses, art centres, or with the support of wealthy patrons, gildings are denser and their diversity is much greater. Factors of motifs visible in patterns such as form, size, frequency, variety, balance, spacing, etc., reflect unique features of artistic styles. These factors act as benchmarks to help date the manuscripts with an unclear copying date. Preserving manuscripts as a cultural heritage, recorded and handed down to the next generations is of great importance. In this study, the composition, shape, and technical and motif features of the Alanya Museum 487 inventory numbered Qur'an have undefined date of rewriting, and it was constructed in a classical style, preserved in the Konya Manuscript Regional Directorate, and systematically evaluated while dwelling on components, thus ensuring the diversity of designs seen in Sûrebaşı gildings.

Keywords

Qur'an, Gilding, Pattern, Manuscript, Classical Period

\section{Extended Summary}

Humanity has experienced methods of using different places and objects to express the morals they carry within, owing to the belief of own, throughout history. Artworks are a form of embodied reflection of the spirit world. These reflections can be seen as art. Art is one of the significant elements that connect a nation's past to the future. These artworks are a testament to the social and cultural fund of knowledge created by art and constitute the most reliable sources on studies of science, art, and culture required in understanding a civilization.

It is important that, to preserve the manuscripts, which are some of the precious pieces of our cultural heritage commanded from our past to the science and art community so they can be handed down to the next generations while investigating the script, binding, and ornaments.

The composition and originality of pattern design define the ornaments of a manuscript, such as refinement, thoroughness, deftness, and suchlike elements form the workmanship process. The pattern is the element that shows the power of the manuscript's ornament. During pattern preparation, first, composition design, and second, selection of motifs and sizes to be used define the technique to be used. This process is rather important for making an ornament. These two points make the basis of pattern design. Factors of motifs seen in a pattern such as form, size, frequency, variety balance, and spacing, reflect the characteristic features of artistic styles. Meanwhile, these factors are used as benchmarks in dating manuscripts with an unclear copying date.

Another dimension of an ornament is the pattern diversity used in decorating the piece. Maintaining harmony and balance between the patterns is essential as well and this requires profound knowledge and experience of a pattern. In the pieces produced in an art housesustaining its existence only through the patronage of wealthy art benefactors or art centres, it is possible to see the mentioned pattern variety. These patterns adorned with various materials and colours bring attraction, quality, and identity to the piece since it adds a new dimension to the linear pattern in the master's hand. 
This study analyzes and evaluates the sûrebaşı gildings (the gilding adorning the top of the Surahs in the Qur'an), in the Qur'an numbered 487 in the Alanya Museum inventory which is preserved in the Konya Manuscripts Regional Directorate. In the sûrebaşı gildings seen in the Qur'an gilding tradition, the applied patterns, pattern variety in the same Qur'an and elements used in creating the diversity form the topic of the research.

Analysis of the visuals, which forms the basis of the study, uses digital images provided by KYEBM. To clarify unclear points from the images KYEBM was visited and the images were closely examined, taking the necessary protective measures. Additionally, in the Qur'an has an unclear copying date, the seal on the leaf numbered $2 \mathrm{~b}$ belongs to Suleiman the Magnificent, as stated on the Alanya Museum archive form information.

Unusually, the pattern designs of the 112-piece sûrebaşı gilding involved in the Qur'an we focused on are different. This study sheds light on how to create this rich variation without repetition in patterns used in the decoration of a manuscript. This study defines the factors providing original pattern designs. Sûrebaşı gildings were examined according to their order in the Qur'an and this study detects a possible sequence or code used. Further, in this study, sûrebaşı gildings were evaluated in detail by comparing them with each other.

Sûrebaşı gildings were subjected to a systematic analysis considering the elements that provide the variety. The design features of pattern, according to the text background colour, text colour, the motifs used with technical features, and colour, were evaluated in five groups. According to this assessment, the obtained quantitative data was shared in the investigation section. The presence of the spiral line on the motifs, thin branches, balanced use of the golden-dark blue color ratio in the background painting, tone of the dark blue color, and size and frequency of the motifs are the characteristics of the classical style in ornamental art and are significant findings in the investigated ornaments.

To obtain the variety seen in sûrebaşı gilding's design composition, features of the text, text background color, and motif form of separating the background, an artistic style is seen in adorning, technique, and motifs used. Additionally, different workmanship has been seen in sûrebaşı gildings. This situation gives rise to thinking around the possibility that more than one artist worked under the control of an individual for the decoration of the Qur'an. The situation requires disciplined work, which suggests the possibility that the piece was made under an authority's counseling such as head of painting or in an art house.

As a result of the elaborative analysis in the study, pattern design, balance of usage of gold and dark blue colors in the background, rosette (decorative figure of the sun) 
usage of gold in three forms, shiny, semi-opaque and opaque, presence of spiral line located on the motifs, motif forms, balance, spacing, colour, and technical features suggest that the sûrebaşı gildings were made in the classical Ottoman style. However, the presence of marks belonging to pre-classical ornaments should not be ignored. In addition, a code or sequence was not detected by ordering the sûrebaşı gildings in terms of pattern features. Moreover, despite the limited quantitative factors that make the composition, the qualification of the ornamentation in manuscript is unique. 


\section{Giriş}

Osmanlı kitap sanatlarında gelişim süreci ve üslup, Fatih Sultan Mehmet dönemin$\mathrm{de}^{1}$ nakkaşhanenin kurulmasıyla şekillenmeye başlamıştır. II. Bayezid devri; Sultan’ın ilme, kitaba, sanata verdiği önem ve desteğinden dolayı, kitap sanatlarında klasik öncesi yaşanan bir geçiş devri olarak değerlendirilebilir. II. Bayezid, Amasya’da şehzadelik yıllarından itibaren pek çok âlim, sanatkâr ve şaire çalışmalarından dolayı ihsanlarda bulunmakla beraber saltanatı (1481-1512) devraldıktan sonra da devlet tarafından bu çalışmalar desteklenmiştir. Özellikle hocası Şeyh Hamdullah'ın hat sanatında yapmış olduğu yenilik, doğal olarak kitap yazımına ve sayfalardaki tezyinata da yansımıştır. Tezyinatta bilhassa motif ve renk konusunda etkileyen Timurî-Herat ve sadeliğiyle öne çıkan Türkmen üslupları, Osmanlı topraklarında tezhibe yön veren belirgin üsluplardır. Sadelik, simetri, değişen form anlayışı bu dönem tezhip sanatının en belirgin üslup özellikleridir. ${ }^{2}$

16. yüzyılın başlarında Şah I. İsmail'in (1502-24) aralarında müzehhiplerinde olduğu Horasanl1-Heratlı sanatçıları, ilk payitaht olan Tebriz'e getirmesiyle ve Tebriz'deki Akkoyunlu sanatçıların da katılımıyla incelmiş zarif bir üslubun varlığı görülür. Yavuz Sultan Selim'in 1514 Çaldıran zaferi sonrasında, Osmanlı saray nakkaşhanesinde çalıştırılmak üzere Herat, Tebriz ve Şiraz'dan İstanbul'a getirilen sanatçılar, Saray Nakkaşhanesi'nin Acem Nakkaşları Bölüğü’nü oluşturmuştur. ${ }^{3}$ Tebriz'den getirilen üstadlardan biri de Ağa Mirek'in öğrencisi Şahkulu'dur. ${ }^{4}$ Bu bölüğün sahip olduğu sanat anlayışıyla, nakkaşhanede var olan anlayış kaçınılmaz olarak bir etkileşim sürecinde harmanlanarak yeni bir sanat üslubu ortaya çıkmıştır. Sentezlenen bu sanat görüşüyle, Osmanlı "klasik üslup” özelliklerini taşıyan eserler uzun süre üretilmeye devam edilmiştir. ${ }^{5}$

1 İlme ve sanata büyük önem veren II. Mehmet, her ikisini de bünyesinde toplayan "kitap"1n üretilmesi için Topkapı sarayında bir nakkaşhane kurmuştur. Burada yerli ve doğu memleketlerinden gelen hattat, nakkaş, müzehhip, mücellit ve talebeleri 40-50 kişilik bir grup halinde çalışmışlardır. Bk. Süheyl Ünver, "İstanbul Fethinden Sonra İlim ve Sanat," Fethin 511. Yıldönümü Konferanslarl, (İstanbul: İstanbul Üniversitesi Yayınları, 1964) 16-28. Fatih dönemi yazma eser tezyinatı; üslup, teknik, motif ve renkleri, diğer dönemlerden ayrılan karakteristik özelliklere sahiptir. Bk. Seher Aşıcı, "Fatih Devri Tezhip Üslubu" (Sanatta Yeterlilik Tezi, Marmara Üniversitesi, 2007) 211-265.

2 II. Bayezid döneminde padişah ve saray çevresine sunulan kitapların büyük bir kısmı, Kur'an-1 Kerim olmuştur. Dolayısıyla tezhip sanatına yön veren form ve biçimler Mushaf yazma geleneğinde kabul gören yazı çeşidi ve sayfa biçimi çevresinde gelişmiş̧ir. Bk. Gülnihal Küpeli, "Tezhip Sanatında Yenilik Arayışları: II. Bayezid Dönemi (1481-1512)," Hat ve Tezhip Sanatt, ed. Ali Riza Özcan (Ankara: Kültür ve Turizm Bakanlığı Yayınları, 2015), 321-341.

3 Zeren Tanındı, "Başlangıcından Osmanlı’ya Tezhip Sanatı," Hat ve Tezhip Sanatı, ed. Ali Rıza Özcan (Ankara: Kültür ve Turizm Bakanlığı Yayınları, 2015), 266.

4 Banu Mahir, “Osmanlı Bezeme Sanatlarında Saz Üslubu,” Hat ve Tezhip Sanatı, ed. Ali Rıza Özcan (Ankara: Kültür ve Turizm Bakanlığı Yayınları, 2015), 381.

5 Klasik üslupta eserlerin verildiği XVI. yüzyıl, Osmanlı sanatında genel olarak "klasik dönem” olarak da anılmaktadır. Bk. F. Çiçek Derman, "Osmanlı'da Klasik Dönem Kanûnî Sultan Süleyman (1520-1566) Türk Tezhip Sanatının Muhteşem Çağı: 16. Yüzyıl," Hat ve Tezhip Sanatı, ed. Ali Rıza Özcan (Ankara: Kültür ve Turizm Bakanlığı Yayınları, 2015), 343-359. Ayla Ersoy, Türk Tezhip Sanatı (İstanbul: Akbank Yayınları, 1988), 58-65. 
Şahkulu (1520-1556) ve öğrencisi Karamemi’nin (1557-?) sernakkaşlığ dönemlerinde ${ }^{6}$ nakkaşhabede üretilen eşsiz eserlerde görülen saz üslubu ve naturalist üslup, dönemin dikkati çeken yeniliklerindendir. Nakkaş Karamemi serbest, hareketli naturalist kompozisyonları, klasik tezyini motiflerlerle bir üslup bütünlüğü içerisinde kaynaştırmıştır. Muhibbî Dîvan'ları (973/1565 tarihli İÜK 5467, 971/1563 tarihli NK 3873), Süleymannâme (965/1558 tarihli TMSK H 1517), Kur'an-1 Kerimler (962/1554-55 tarihli TMSK EH 49) başta olmak üzere pek çok imzalı veya Karamemi üslubunun özelliklerini yansıtan eserler, sanatçının sernakkaşlığı döneminde üretilmiş klasik tezyinatın nadide örnekleridir. ${ }^{7}$ Ayrıca 16. yüzyıla ait TMSK HS $5^{8}$, TMSK YY 9999, TMSK K 23 ve TİEM 383 numaralı Kur'an-1 Kerim nüshaları, Osmanlı dönemi klasik üslup tezyinatının en güzel örneklerindendir.

Yazma eserler arasında Mushaflar, ${ }^{10}$ tezhip sanatının uygulandığ 1 alanlar $1{ }^{11}$ içermesi açısından ilk sıralarda yerini almaktadır. Farklı dönem ve coğrafyalarda istinsah edilen Mushaflarda, aynı tezyinat alanlarının tekrarlandığ 1 , klasik kurallara sadık kalınarak devrin sanat anlayışı ile farklı üsluplarda mükemmel eserler ortaya çıkarma amacı güdüldüğü görülmektedir. Bu amaç doğrultusunda tezyin edilmiş, sanat değerine sahip pek çok Kur'an-1 Kerim nüshas1, müze ve kütüphanelerin yazma eser koleksiyonlarinda bulunmaktadır.

6 Topkapı Sarayı Nakışhanesi'nde hocası Şahkulu'nun vefatından (1556) sonra 1 Rebiü'l-âhîr 964/1557 tarihinde hassa nakkaşbaşlığına tayin olunmuştur. Bu görevi kaç yıl sürdürdüğü tam olarak bilinmemekle beraber Sultan II. Selim (sl.1566-74) döneminde hayatta olduğu bilinmektedir. Bk. Gülbin Mesara, "Kanuni Sultan Süleyman'ın Sernekkaşı Karamemi," Hat ve Tezhip Sanatı, ed. Ali Rıza Özcan (Ankara: Kültür ve Turizm Bakanlığı Yayınları, 2015), 362.

7 Mesara, “Kanuni Sultan Süleyman'ın Sernekkaşı Karamemi," 361-77.

8 "Ahmed Karahisârî Mushaf' 1 " adıyla tanınan nüsha 1540-55 yıllarına tarihlendirilmektedir. Hattının Karahisârî talebesinden Hasan Çelebi tarafindan tamamlandığı sanılan Mushaf'ın bezemesi masraf defterlerine göre1584-96 arasında 12 yıl devam etmiştir. Mushaf'ın her sayfasında karşllıklı ikişerden dört koltuk bezemesi yer almaktadır ve toplam 2360 koltuk tezhibi bulunmaktadır. Bk. Derman, "Osmanlı'da Klasik Dönem Kanûnî Sultan Süleyman (1520-1566) Türk Tezhip Sanatının Muhteşem Çağı: 16. Yüzyıl,” 347.

9 Hattat Ahmed Karahisârî hattıyla 1546-47'de istinsah edilmiştir. Karamemi'ye ait olduğu şüphe götürmeyen tezyinatında, serlevha tezhibi ve diğer bezemeleriyle bir baş eserdir. Bk. Mesara, “Kanuni Sultan Süleyman'ın Sernekkaşı Karamemi," 375.

10 Kur'an sahifelerinin kitap haline getirilmiş şekline "Mushaf" denilir. Bk. Tayyar Altıkulaç, Günümüze Ulaşan Mesâhif-I Kadime: İlk Mushaflar Üzerine Bir İnceleme (İstanbul: İslam Tarih, Sanat ve Kültür Araştırma Merkezi, 2015), 55; Hz. Ebu Bekir (632-634) döneminde, Kur’an-1 Kerîm iki kapak arasına alınmış ve tek bir cilt haline getirilmiştir. Bk. Abdülhamit Birışık, "Kur'an," İslam Ansiklopedisi, c.26 (Ankara: Türkiye Diyanet Vakfı Yayınları, 2002), 383-388; Mehmet Memiş, "Türk Hat Sanatında Hz. Muhammed Sevgisini Konu Alan Çalışmalar," Art-Sanat 14 (2020): 246-248, erişim: https://dergipark.org.tr/tr/download/article-file/1233425.

11 Mushaf tezyinatı geleneğinde; zahriye, serlevha, unvan (başlık) ve hatime (ketebe) sayfaları, sûrebaşı, cüzbaşı, koltuk, beynes sütur, tığ, gül ve durak tezhipleri yer almaktadır. Bk. Gülnur Duran, "Tezhip Sanatının Kullanım Alanları,” Íslam Ansiklopedisi, c.41 (İstanbul: Türkiye Diyanet Vakfı Yayınları, 2012), 63-65. 
Sûrebaş $1^{12}$, Kur'an-1 Kerîmlerde genellikle metnin yazıldığ 1 hat çeşidinden farklı bir hatla veya farklı renk mürekkeple, sûre bilgilerinin (sûre ad1, âyet sayısı ve nazil olduğu yer) verildiği bölümdür. Kur'an metni içerisinde sûrenin bittiği ve yeni bir sûrenin başladığı yerin daha kolay anlaşılabilmesi için Hicrî II. yüzyıldan itibaren Mushaflarda sûrebaşında çeşitli tezyinat örneklerinin varlığı görülmektedir. ${ }^{13}$ VIII. yüzyıl başlarında deri üzerine yazılmış, kareye yakın ölçüde tasarlanmış cüzün (TIEEM, ŞE. No.80, kat.4) tezhipleri ilk örnekler arasında sayılabilir. Eserin yapraklarında sûrebaşına işaret eden, kırmızı çiçekli, yeşil yapraklı iri bir dal görünümünde, bazen diziler halinde basit bitkisel bezemeler görülür. Rulo halinde parşömen üzerine iri kûfi hatla iki taraflı yazılmış eserde (TIEM, ŞE. 12727, kat.9) rulonun başlangıcında, temel tasarımı; altın kesişen bantlar ve yarım daireler olan unvan tezhibi yapılmış, sûrebaşının iki tarafına iri bitkisel motifler eklenmiştir. ${ }^{14}$ Sûrelerin başlangıçlarını belirlemek için kullanılan yatay dikdörtgen formların tasarımları X. yüzyıldan başlayarak zenginleştiği görülmüştür. Sûrebaşlarında altın, yeşil ve kırmızı renkli bitkisel süslerin yer aldığı, 383/993 tarihli Kâtip Muhammed b. Ahmet b. Yasin hattıyla Isfahan'da istinsah edilen ve dört cilt halinde hazırlanan Kur'an (T.453-456, kat.35), bu örneklerden biridir. ${ }^{15}$

Çalışma nitel araştırma yöntemi doğrultusunda; literatür taraması, örnek eserlerin tezhiplerinin incelenmesi yoluyla gerçekleştirilmiştir. Tezhip sanatının geçmişteki örneklerinin incelenip analiz edilerek bilim ve sanat camiasına kazandırılması amaçlanmıştır. Mushaf tezyinat geleneğinde görülen sûrebaşı tezhiplerinde kullanılan desenler ve çeşitliliği oluşturmada kullanılan unsurlar araştırılmıştır. Bu bağlamda klasik üslupta tezyin edilmiş, Konya Yazma Eserler Bölge Müdürlüğü (KYEBM)'de korunan Alanya Müzesi 487 envanter numaralı Kur'an-1 Kerim'in tezyinatında yer alan sûrebaşı tezhipleri ve desen çeşitliliğini sağlayan unsurların araştırılması çalışmanın konusunu oluşturmaktadır. Yapılan literatür araştırmalarında incelenen eserler arasında yer alan; IÜKK A 6662 (914/1508), ${ }^{16}$ İ̈KK A 6552, TMSK A 5 (1503-4), SK

12 Yazma kitaplarda fasıl veya bahir adı verilen her bölümün başında bulunan, Mushaflarda ise her sûrenin başladığı yeri gösteren tezhipli alanlara başlık (unvan) tezhibi (ara başlık, bahir başı, fasıl başı, sûrebaşı, cüzbaşı) olarak tanımlanmaktadır. Bk. Nilüfer Kurfeyz, Tezhip (İstanbul: Tatav Yayınları, 2003), 6. Başlık tezhibinde; eser, konu veya sûre hakkında bilgiler veren yazılar yer almaktadır.

13 Banu Mahir, “Topkapı Saray Kütüphanesi’nin Kur'an Koleksiyonu,” Türkiyemiz Kültür ve Sanat Dergisi 22/67 (1992), 16-18; Altıkulaç, Günümüze Ulaşan Mesâhif-I Kadime: Illk Mushaflar Üzerine Bir İnceleme, 2015. Ayșe Celasin, "Tezhip Sanatında Emevî Dönemi Sûrebaşı Bezemelerinin Yeri," Art-e 6 (2013): 120138, erişim: https://dergipark.org.tr/en/pub/sduarte/issue/20732/221567

14 Tanındı, "Kur’an-1 Kerim Nüshalarının Ciltleri ve Tezhipleri," 1400. Yllında Kuranı Kerim, Türk ve İslam Eserleri Müzesi Kuranı Kerim Koleksiyonu, ed. Müjde Unustası (İstanbul: Antik A.Ş., 2010), 90-91.

15 Zeren Tanındı, dört cilt halinde hazırlanan eserin bir cildinin eksik olduğunu ifade etmektedir. Tanındı, "Başlangıcından Osmanlı'ya Tezhip Sanatı," 243.

16 Şeyh Hamdullah'ın yazdığı Kur'an-1 Kerim nüshalarında yer alan sûrebaşlarında; zemin ayırmada kullanılan motif ve form, simetrik ve serbest desen tasarımı, renk ve motif açısından, incelenen Mushaf'da yer alan sûrebaşlarına benzer özellik gösteren sûrebaşı örneklerine rastlanmıştır. Bk. Ayșe Tanrıver Celasin, "XV.-XIV. Yüzyıl Osmanlı Tezhip Sanatı Bağlamında Şeyh Hamdullah Mushafları Sûrebaşı Bezemelerinin Değerlendirilmesi," (Doktora tezi, Süleyman Demirel Üniversitesi, 2014). 
Hasan Hüsnü Paşa 1 (949/1542), TİEM 506 (988/1580-81), SK Laleli 16 (990/1582) ve SK Sultan I. Ahmed 14, numaralı Kur'an-1 Kerimlerin sûrebaşları incelenmiştir. 16. yüzyılda hazırlanan bu eserlerde görülen sûrebaşı tezhiplerinde, çalışmaya konu olan Mushaf'ın sûrebaşı tezhiplerinin; kompozisyon, desen tasarımı, renk ve motif açısından benzer özellikler gösteren sûrebaşı örneklerine rastlanmıştır.

Çalışmada eserin görselleri, KYEBM'den temin edilen dijital görüntüler üzerinden incelenmiştir. Ayrıca Mushaf'ın ölçülerini almak, kullanılan altının; renklerin tespiti, kondisyonu, oksitlenmenin varlığı, uygulama tekniği (sıvama, yapıştırma) ${ }^{17}$ gibi hususları çözmek için, KYEBM'ye gidilmiş ve eser gerekli koruma tedbirleri alınarak yakından incelenmiştir. Çalışmada ele alınan yüz on iki adet sûrebaşı (başlık) tezhibi tek tek analiz edilmiştir. Analiz sonucunda elde edilen bulgulara dayanılarak sûrebaşı tezhiplerinin, ortak benzerliklerini veya farklılıklarını ortaya koyan unsurlar belirlenmiştir. Belirlenen bu unsurların daha iyi anlaşılabilmesi için G. 1'de verilen şema oluşturulmuştur. Sûrebaşı tezhiplerinin incelenmesinde şemada verilen unsurlar sırasıyla sistematik olarak ilgili bölüm içerisinde ele alınmıştır.

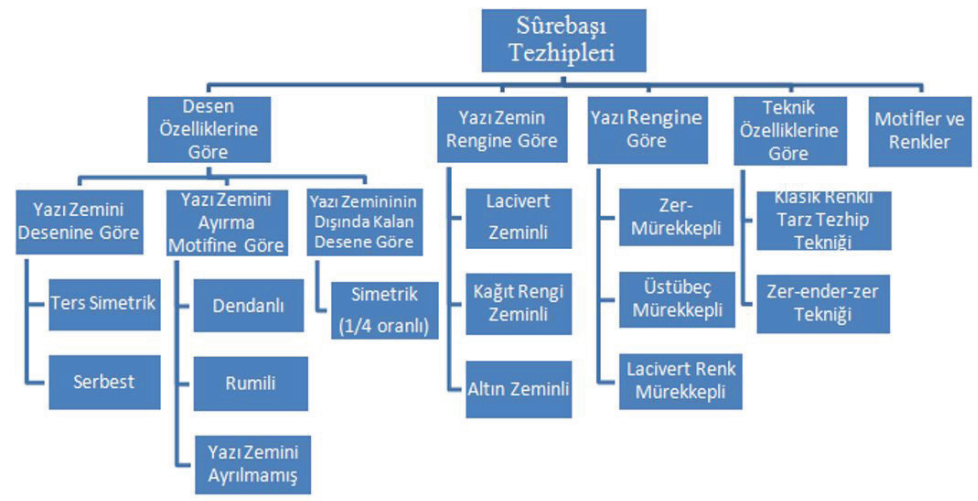

G. 1: Sûrebaş1 tezhiplerinin incelenmesinde izlenilen sistematik yolu gösteren şema (Ummuhan Kaçar, 2020)

\section{Konya Yazma Eserler Bölge Müdürlüğü'nde Korunan Alanya Müzesi 487 Envanter Numaralı Kur'an-ı Kerîm'in Sûrebaşı Tezhiplerinin Değerlendirilmesi}

\subsection{Kur’an-ı Kerîm'in Genel Özellikleri}

Mushaf, 30.10.1967 tarihinde Türk İslam Eserleri Müzesi’nden Alanya Müzesi'ne devredilmiştir. Daha sonra 15.01.2016 tarihinde Konya Yazma Eserler Bölge

17 Tezhipte kullanılan ana malzemelerden olan altının hazırlanması ve uygulanması, geleneksel bilgi gerektirmektedir. Bk. Faruk Taşkale, "Tezhip Sanatının Kullanım Alanları” (Yüksek Lisans Tezi, Mimar Sinan Güzel Sanatlar Üniversitesi, 1994), 52-56. 
Müdürlüğü'ne restorasyon için gönderilmiş ve hâlen burada korunmaktadır ${ }^{18}$. Henüz restorasyonu yapılmamış ve envanter numarası verilmediği için, Alanya Müzesi’nin vermiş olduğu envanter numarasıyla kayıtlıdır. Ayrıca Mushaf'ın iç kapağına yapıştırılmış halde bulunan nota ${ }^{19}$ istinaden, eserin hazırlandıktan sonra Süleymaniye Camii'nde muhafaza edildiği ve 2 Ağustos 1227 (M. 14 Ağustos 1812) tarihinde Süleymaniye Camii’nden adı belirtilmeyen bir müzeye nakledildiği anlaşılmaktadır.

Mushaf 290x210x65 mm ölçülerindedir. Kahverengi deri cildi ${ }^{20}$ miklepli ve soğuk baskı tekniğiyle hazırlanmıştır. Cildin alt ve üst kaplarında dikey, miklepte ise yatay düzleme yerleştirilmiş şemse ${ }^{21}$ formlu, sade bir bezeme mevcuttur. Kenarları dendan motifiyle s1nırlandırılan şemsede, bulut, hatayi ve hançerî yapraklar görülmektedir²2 (G. 2a).

Yakut tarzında ${ }^{23}$ kaleme alınan Mushaf'ın yazımında; reyhanî, sülüs, muhakkak, nesih hatları, sûrebaşı bölümlerinde ise muhakkak ve tevkii hat çeşitleri ${ }^{24}$ kullanıl-

18 Mushaf'a ait bilgiler Konya Yazma Eserler Bölge Müdürlüğünden temin edilmiştir. KYEBM; satın alma, bağış ve devir yoluyla çeşitli kişi, kütüphane ve kurumlardan pek çok yazma ve nadir eseri bünyesine katmıştır. Bugüne kadar yüz bir farklı yazma ve nadir eser koleksiyonu kuruma devredilmiştir. Bu koleksiyonlarda; 19.652 cilt içerisinde yaklaşık 40.000 el yazması olmak üzere toplanda 140.000 eser korunmaktadır. Ayrıca yurtiçi ve yurtdışından temin edilen 48226 yazma, 9405 nadir matbu, 54 levha ve 2061 belge fotoğraf olmak üzere 59746 eserin dijital arşivine araştırmacıların erişimine imkân sağlanmaktadır.

19 Mushaf'ın iç kapağında bulunan kütüphane görevlileri tarafından yazıldığı düşünülen bilgilendirme notunda:

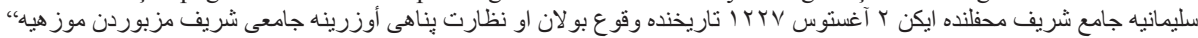
"نقل اولونمشدر موزه"

"Süleymaniye Cami-i Şerif mahfilinde iken 2 Ağustos 1227 tarihinde vuku bulan o nezâreti penâhi üzerine camii şerif mezbûrdan müzeye nakil olunmuştur” yazmaktadır.

20 Cilt, kitap yapraklarını bir arada tutmak için kullanılan koruyucu kaba denilmiştir. Kaplar önceleri rulo halinde kullanılmış, daha sonra kitabın şeklini almıştır. Bk. Hasan Özönder, Ansiklopedik Hat ve Tezhip Sanatları Deyimleri, Terimleri Sözlüğü (Konya: Sebat Ofset, 2003), 24. Arapça “deri” anlamına gelen cildi, yapma işine "telcid” (cilt), yapan kişiye ise "mücellid” denilmektedir. Bk. Zeynep Balkanal, "Bilgi ve Sanatı Kaplayan Sanat: Ciltçilik," Türkler Ansiklopedisi, c.12 (Ankara: Yeni Türkiye Yayınları, 2002), 545. Klasik bir cilt; alt -üst kapak, sırt, alt kapağa eklenen sertab ve bunun devamı olan miklep bölümlerinden oluşur. Kemal Çı̆̆, Türk Kitap Kapları (İstanbul: Yapı ve Kredi Bankası Yayınları, 1971). Klasik dönemde gelişmiş olan cilt çeşitleri, malzemesi, bezemesi ve tekniğine göre gruplara ayrılarak incelenmiştir. Ahmet Saim Arıtan, “Ciltçilik,” İslam Ansiklopedisi, c.7 (İstanbul: Türkiye Diyanet Vakfi Yayınları, 1993), 554.

21 Klasik Osmanlı cilt sanatı bezemesinde kullanılan, aslı güneşe benzetildiği için bu ismin verildiği yuvarlak veya beyzî (oval) form, "şemse”" olarak adlandırılmaktadır. Yılmaz Özcan, Türk Kitap Kaplarında Şemse Motif (Ankara: Kültür Bakanlığı Yayınları, 1990), 2. Cilt üzerine yapılan tezyinat dönemlere göre farklı şekillerde yapılmıştır. Şemseler Selçuklu ve XV. yüzyıl Osmanlı ciltlerinde genellikle yuvarlak, XVI. yüzyıldan itibaren de beyzî olarak yapılmıştır. Balkanal, "Bilgi ve Sanatı Kaplayan Sanat: Ciltçilik," 552. Cilt bezemeleri, tüm yüzeye yapılabildiği gibi, bazı ciltlerin yalnız göbek kısmına bezeme yapılmış, köşeler boş bırakılmıştır. İsmet Binark, Eski Kitapçılık Sanatlarımız (Ankara: Kazan Türkleri Kültür ve Yardımlaşma Derneği Yayınları, 1975), 10.

22 Geleneksel Türk sanatlarında; rûmi, bulut, münhani, çintemani, hatayi, penç, yaprak gibi çeşitleri olan, üsluplaştırılmış, yarı üsluplaştırılmış, doğal veya hayal mahsulü motifler, bezemeyi oluşturan ana elemanlardır. Bk. İnci A. Birol ve F. Çiçek Derman, Türk Tezyini Sanatlarında Motifler (İstanbul: Kubbealtı Neşriyatı, 2011).

23 İncelenen Mushaf'ın hat tasarımında; ilk ve son satırı muhakkak, orta satırı sülüs hattıyla, bu üç satırın arasında ise dörder satırlık iki kıta nesih satırların yer alması sebebiyle, yakut tarzında yazılan Karahisâri Mushaf'ına benzemektedir. Bk. Hüseyin Gündüz, "Türk Hat Sanatında Şeyh Hamdullah ve Ahmed Karahisârî," Hat ve Tezhip Sanatı, ed. Ali Rıza Özcan (Ankara: Kültür ve Turizm Bakanlığı Yayınları, 2015), 75-87. Muhittin Serin, "Yakut El Musta’sımî," İslam Ansiklopedisi, c.43 (İstanbul: Türküye Diyanet Vakfi, 2013), 291-293.

24 Çalışmada incelenen Mushaf'ın yazımında kullanılan yazı çeşitlerinin tespit edilmesinde hattat Dr. Öğr. Üy. Hüseyin Öksüz Bey’in görüşü alınmıştır. 
mıştır (G. 2b). İstinsah bilgilerine ulaşılamayan Mushaf'ın 2b varağında Kanuni Sul$\tan$ Süleyman'ın mührü ${ }^{25}$ ve 414 a varağında da vakfiye metni yer almaktadır. Ayrıca Mushaf'ın sonuna, dua ve salâvatların verildiği dua metni, hatim duası ve 413a'da Farsça yazılmış "tefe'ül'ül isnat" metinleri ilave edilmiştir. ${ }^{26}$

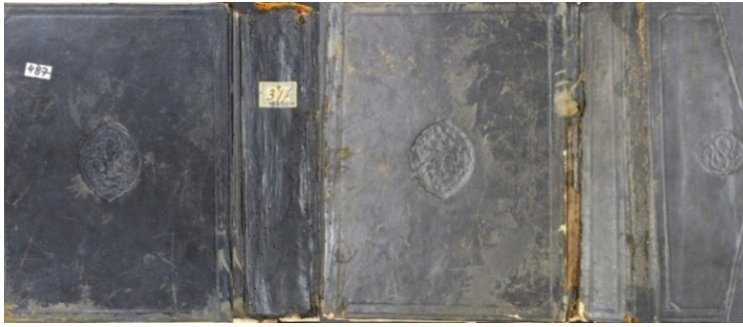

G. 2a: Alanya Müzesi 487 numaralı Mushaf'ın cildi: üst kapak, sirt (dip), alt kapak, sertab ve miklep

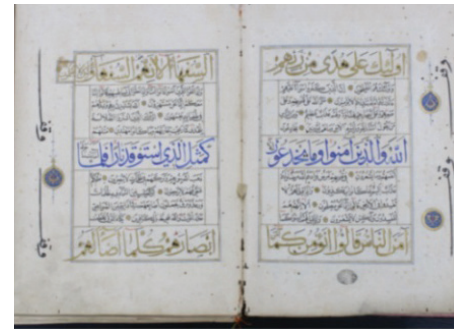

G. 2b: Alanya Müzesi 487 numaralı Mushaf'in sayfa tasarımı (v. 2b-3a)

Tezyinat açısından incelendiğinde, Mushaf'ta 1b-2a varaklarında tam sayfa dikdörtgen formda serlevha tezhibi ${ }^{27}$ yer almaktadır (G. 3a, G. 3b). Serlevhada diş pervaz bölümü çoğu zaman düz dikdörtgen iklil, kubbeli veya her iki formu birleştiren mürekkep (terkip edilmiş) formda hazırlanır. ${ }^{28}$ İncelenen eserde v. 1b'de Fatiha sûresi, v. 2a'da ise Bakara sûresinin ilk dört ayetinin yazılı olduğu serlevha, iklil formda hazırlanmıştır. Serlevha tezhibi; ortada enine dikdörtgen yazı alanı, yazının iki tarafında koltuklar, üst ve alt başlık ile dış pervaz bölümlerinden oluşmaktadır. Bölümleri birbirinden ayırmada ise lacivert cetvellerin kullanıldığı görülmektedir. Ayrıca Mushaf'da sûrebaşı tezhipleri, gül ve duraklar mevcuttur. Sayfa tasarımında görülen koltuk bezeme alanları boş bırakılmıştır.

25 Alanya müzesi arşiv fişinde, Mushaf’’n 2b varağında yer alan mührün, Kanûni Sultan Süleyman’a ait olduğu belirtilmektedir.

26 Varak 413a'da yer alan Farsça metinde; Hz. Ali’nin rivâyet ettiği hadis-i şerif kaynak gösterilerek tefe'ülün nasıl yapıldığı tarif edilmektedir (Çeviri: Fatemeh Rashidi). Bk. Yusuf Ziya Sümbüllü, “İlm-i Tefe'ül ve Tefe'ül-Name (Kur'an Falı) Üzerine Bir Değerlendirme," Uluslararası Sosyal Araştırmalar Dergisi 1/2, (Kış 2008), 388. http://www.sosyalarastirmalar.com/cilt1/sayi2/sayi2pdf/sumbullu_yusuf_ziya.pdf.

27 El yazması kitaplarda metnin başladığı, dibace de denilen sayfalara, serlevha denilmektedir. Sözlükte "baş" anlamındaki Farsça "ser" ile Arapça "levha” kelimelerinden oluşan serlevha bir yazının başlığı anlamına gelmektedir. Bk. Duran, “Tezhip,” 567.

28 Zahriyeden sonra en yoğun bezemenin bulunduğu bu sayfaların tezhibine de "serlevha tezhibi” adı verilmektedir. Bk. Çiçek Derman, “Tarihimizde Mushafların Bezenmesi,” Diyanet İlmi Dergi 46/4 (2010), 137-144. 


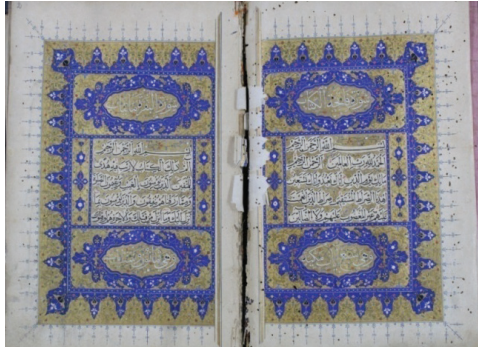

G. 3a: Alanya Müzesi 487 numaralı Kur'an-1 Kerîm'in serlevha tezhibi, v. $1 \mathrm{~b}-2 \mathrm{a}$

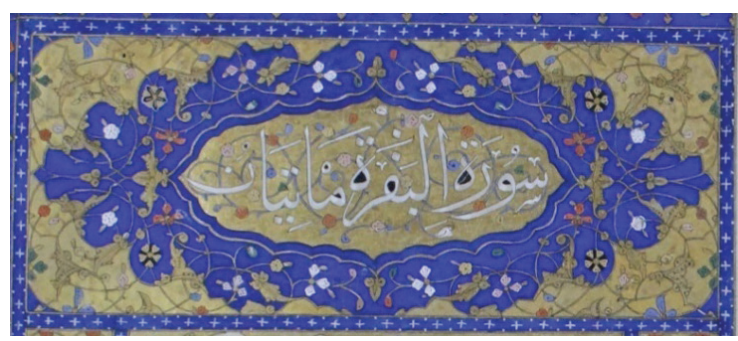

G. 3b: Alanya Müzesi 487 numaralı Kur'an-1 Kerîm'in serlevha tezhibi başlık bölümü detayı, v. 2a

\subsection{Kur’an-ı Kerîm’in Sûrebaşı Tezhiplerinin İncelenmesi}

Mushaf'ta yer alan üç adet sûrenin ${ }^{29}$ (Zümer/v.305b, Fussilet/v.318a, Hadid/v.361a) başında sûrebaşı tezhibi yoktur. Bunun yanında Mushaf'ın sonuna ilave edilmiş, daha önce hakkında bilgi verilen üç adet metnin başında bulunan başlık tezhipleri sûrebaşı formundadır (G. 4). Dolayısıyla Mushaf'ta her biri diğerinden farklı desen tasarımına sahip, yüz on iki adet sûrebaşı tezhibi bulunmaktadır. Mushaf'ın sayfa tasarımına bağlı olarak sûrebaşlarının ölçüleri değişiklik göstermektedir (SK Hasan Hüsnü Paşa 1'de de benzer sayfa tasarımı nedeniyle sûrebaşı tezhipleri farklı ölçülerdedir). Sayfada sülüs satırlara denk gelen otuz yedi adet sûrebaşı, diğerlerine oranla daha büyüktür (G. 4). Atmış adedi iki nesih satır aralığına (G. 7), on beş adedi ise tek nesih satır aralığına denk gelmiştir (G. 14, G. 22). Tasarımlar arasında görülen uyum, denge ve sıralama dikkati çekmektedir.

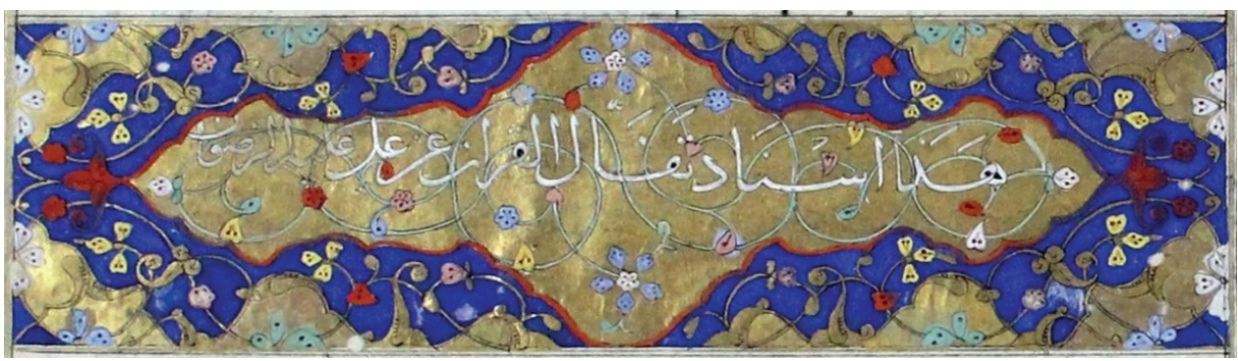

G. 4: Alanya Müzesi 487 numaralı Mushaf'da yer alan başlık tezhibi, v. 413a

29 Sûre sözcüğü Arapça "severe" kökünden türemiştir. Çoğulu sûver olan bu kelime ayrıca yüksek ve güzel bina, kitaptan bir bölüm, derece, menzile, şeref, şan, nişan, alamet, duvar kirişi ve hatıll, yüksek evin bir katı anlamlarına da gelmektedir. Bk. Abdülhamit Birışık, "Sûre," İslam Ansiklopedisi, c.37 (Ankara: Türkiye Diyanet Vakfı Yayınları, 2009), 538. Terim olarak sûre, Kur'an-1 Kerîm'in en küçüğü üç, en büyüğü iki yüz seksen altı âyetten meydana gelen ve İhlâs, Fatiha, Nur gibi isimleri olan yüz on dört bölümden her birine verilen isimdir. Bk. İlhan Ayverdi, Misalli Büyük Türkçe Sözlük, (İstanbul: Kubbealtı Yayınları, 2005), 1:2681. 
Sûrebaşı tezhipleri genel olarak; desen özelliklerine, yazı zemin rengine, yazı rengine, teknik özelliklerine ve motifler-renklere göre beş ana başlık altında incelenmiştir. Desen özellikleri; yazı zemini deseni, yazı zeminini dışından ayıran motif ve yazı zemini dışında kalan desene göre olmak üzere üç grupta ele alınmıştır. Yazı zemini deseni ise kendi arasında ters simetrik ve serbest tasarım başlıkları altında incelenmiştir. ${ }^{30}$ İncelenen Mushaf'ta sûrebaşlarının yazı zemininde; yüz bir adedinde ters simetrik (G. 5), on bir adedinde ise serbest desen tasarımı kullanılmıştır (G. 6). Yazı zeminlerinde ters simetrinin kullanıldığı yerlerde harf ve harekelerin bulunması nedeniyle simetrinin tam anlamıyla uygulanamadığı görülmektedir. Helezonların dallarında, motiflerin yerleştirilmesinde simetride farklılıklar mevcuttur. Serbest tasarımda ise dallar birbirini takip etmeden serbest olarak yazının çevresindeki boşluklara yerleştirilmiştir. Serbest dal çıkışlarında kalp formlu çıkma motifinin kullanılmasının yanında, doğrudan yazıdan çıkan yaprak ve dallar da görülmektedir.

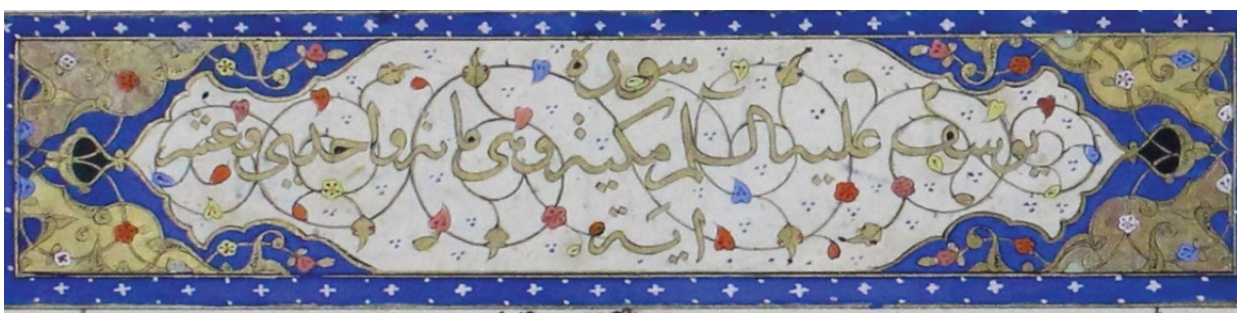

G. 5: Alanya Müzesi 487 numaralı Mushaf, Yusuf sûresi sûrebaşı tezhibi, v. 150a

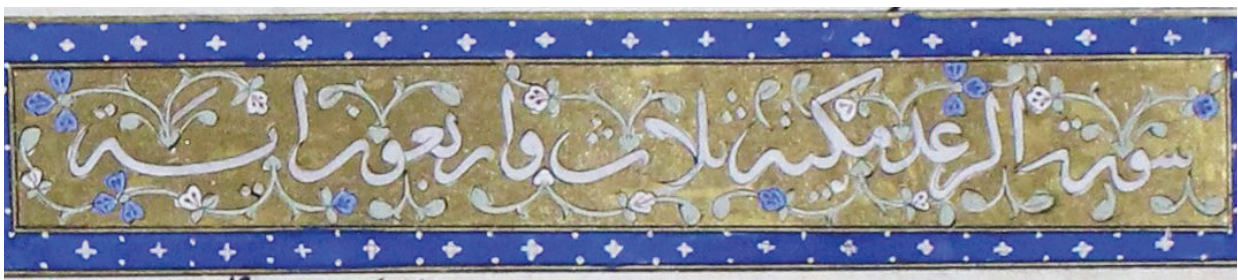

G. 6: Alanya Müzesi 487 numaralı Mushaf, Râd sûresi sûrebaşı tezhibi, v. 159a

Sûre bilgilerinin yazıldığı bölüm (yazı alanı) toplamda doksan yedi adet sûrebaşında, dendan veya rumî motifi kullanılarak pafta içerisine alınmıştır. On beş adedinde ise yazı zemini paftalara ayrılmamış, sûre bilgileri satır boyunca tek satır halinde yazılmıştır. Yapılan değerlendirme sonucunda; tasarım çeşitliliğini sağlamak için sûrebaşında yazı alanının; yetmiş beş adedinde dendan motifiyle (G. 7), yirmi

30 Simetri, desenin kuruluşunda etkin, belirleyici özelliklerdendir. Tam simetri (ulama), kısmen simetri, ters simetri, serbest tasarım (simetrisiz) gibi çeşitleri desen tasarımında kullanılmaktadır. Bk. İnci A. Birol, Klasik Devir Türk Tezyîn̂̂ Sanatlarında Desen Tasarımı (İstanbul: Kubbealtı Neşriyat, 2009), 306-307. Cahide Keskiner, Türk Süsleme Sanatlarında Stilize Çiçekler Hatayi (Ankara: Kültür Bakanlığı Yayınları, 2002), $7-15$. 
iki adedi ise rumî motifiyle paftalara ayrıldığı tespit edilmiştir (G. 8). Dendan ve rumî motifi kullanılarak oluşturulan şemse formu, yatay eksene yerleştirilerek, yazı alanı belirlenmiştir. Doksan yedi adet sûrebaşında farklı şekil ve renkte şemse formu oluşturulduğu görülmektedir. Kullanılan; form, motif, renk ve uygulama kombinasyonları, çeşitliliği sağlamada etkindir. Şemselerin içinde sûrebaşı yazılarıyla birlikte tezyinat da mevcuttur.

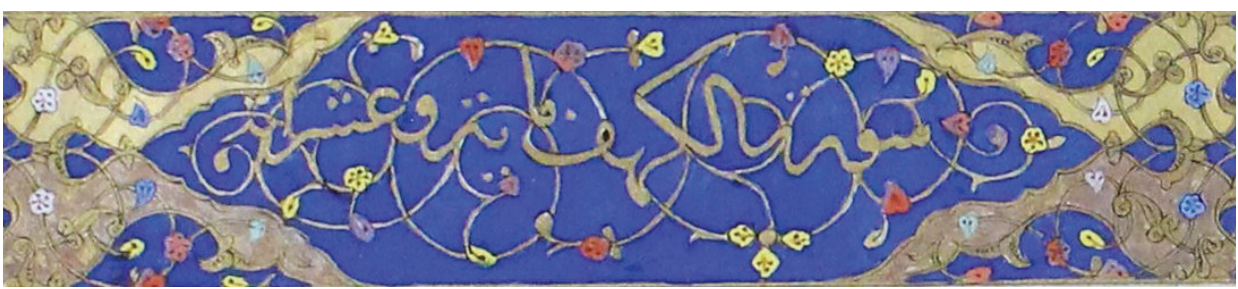

G. 7: Alanya Müzesi 487 numaralı Mushaf, Kehf sûresi sûrebaşı tezhibi, v. 191a

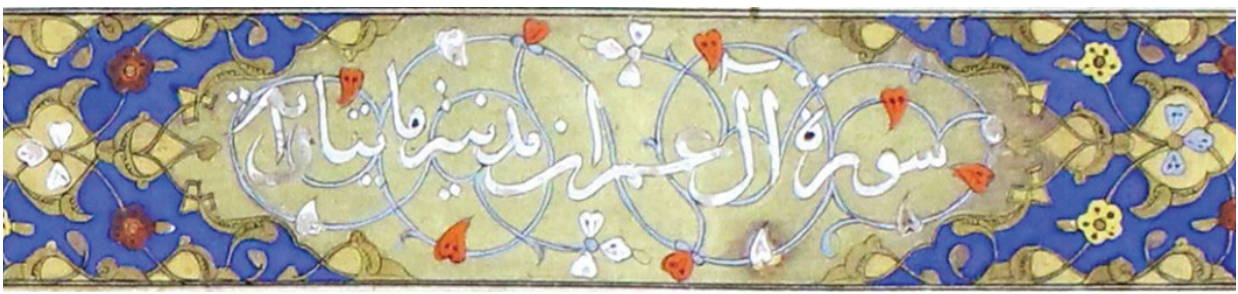

G. 8: Alanya Müzesi 487 numaralı Mushaf, Âli İmran sûresi sûrebaşı tezhibi, v. 32b

Sûrebaşı tezhiplerinin kırk dokuz adedinde, oluşturulan şemselerde salbek ${ }^{31}$ kullanıldığ 1 görülmektedir. Dendan ve rumî kapalı formlarıyla oluşturulan salbeklerin iç zeminin iki adedi tezyin edilmiş, diğerleri yalındır (G. 9). Bununla beraber salbek iç zemininde farklı zemin rengi uygulaması yapılmıştır (G. 10-G. 11). Hac sûresi (v. 217b) sûrebaşında, sûre bilgileri şemse ve salbeklere pay edilerek yazılmıştır (G. 12).

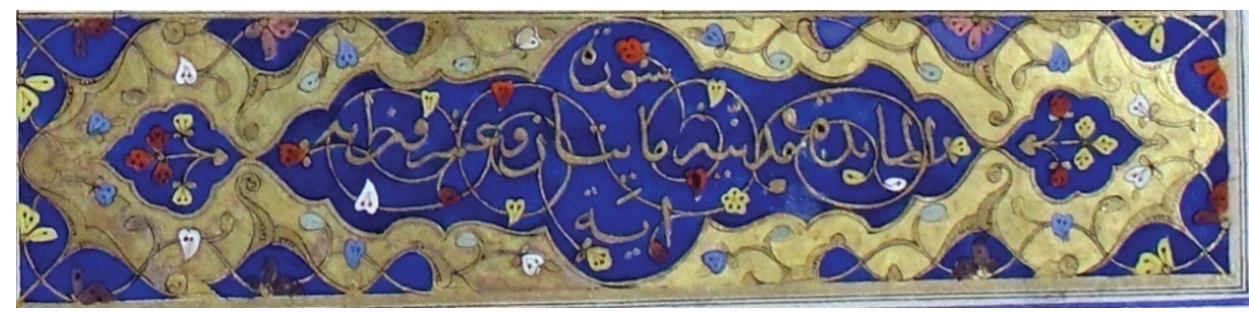

G. 9: Alanya Müzesi 487 numaralı Mushaf, Mâide sûresi sûrebaş1 tezhibi, v. 69b

31 Şemselerin iki ucundaki uzantılara "salbek" denir. Mine Esiner Özen, Türk Cilt Sanatı (Ankara: Türkiye İş Bankası Kültür Yayınları, 1998), 14. 


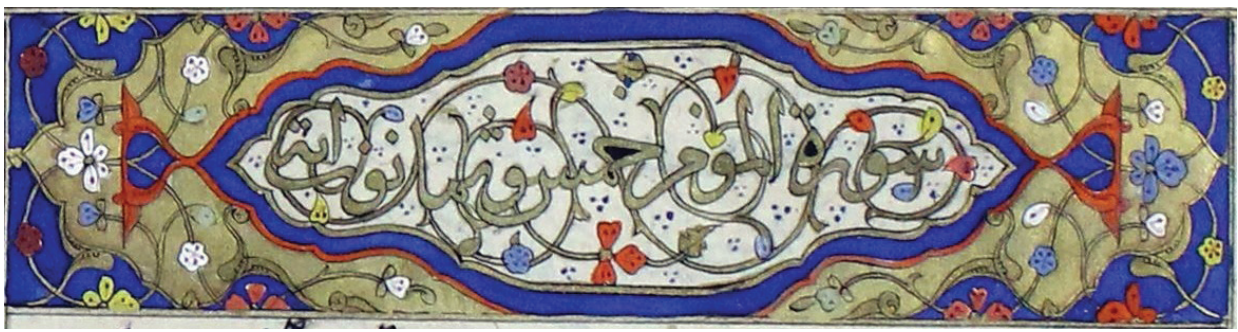

G. 10: Alanya Müzesi 487 numaralı Mushaf, Mü’min sûresi sûrebaşı tezhibi, v. 311b

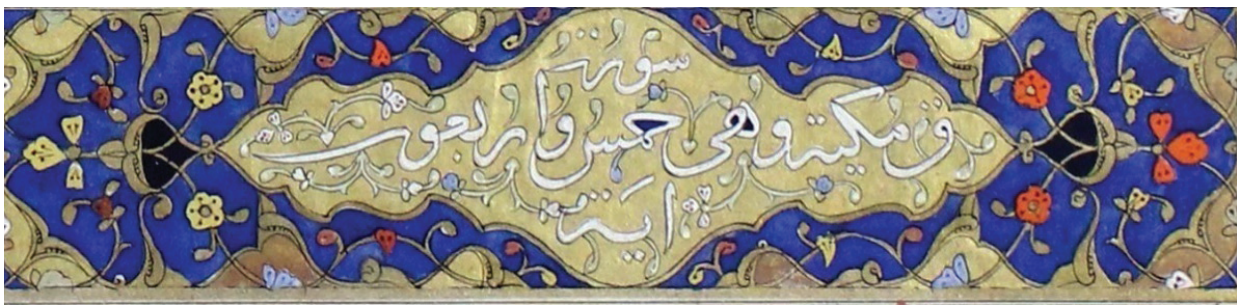

G. 11: Alanya Müzesi 487 numaralı Mushaf, Kaf sûresi sûrebaşı1 tezhibi, v. 346b

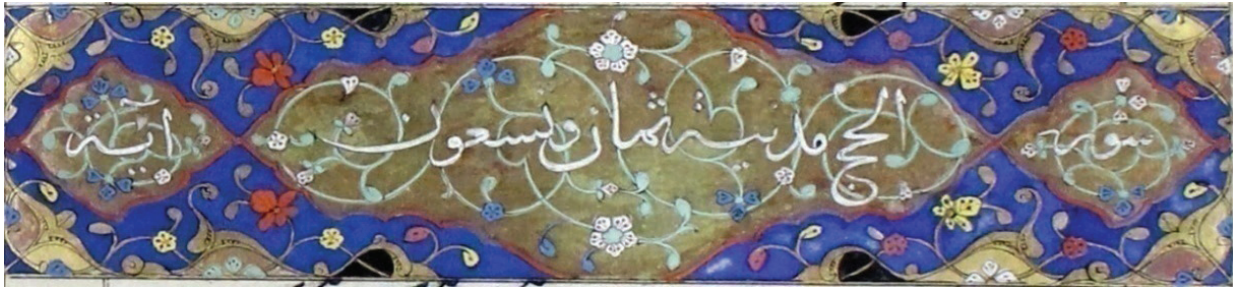

G. 12: Alanya Müzesi 487 numaralı Mushaf, Hac sûresi sûrebaşı tezhibi, v. 217b

Tezyin edilen sûrebaşlarının on beş adedinde, yazı alanının herhangi bir motifle ayrılmadığ 1 belirlenmiştir. Bunlardan on bir adedinde altın zemin üzerine beyaz üstübeç $^{32}$ mürekkebiyle (G. 13), üç adedinde lacivert zemine zer-mürekkeple (G. 14), bir tanesinde de kâğıt zemine zer-mürekkeple sûre bilgileri yazılıdır (G. 15). Yazı zemini paftalara ayrılmayan sûrebaşlarında, zeminde tek renk tercih edilmiştir.

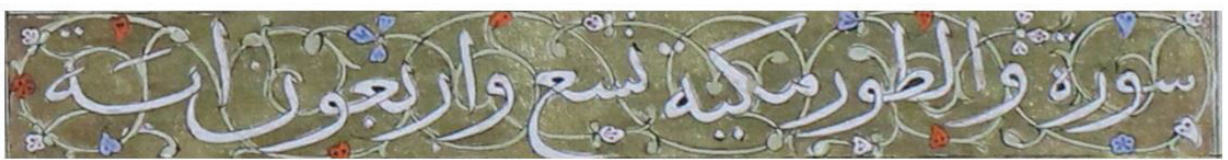

G. 13: Alanya Müzesi 487 numaralı Mushaf, Tûr sûresi sûrebaşı tezhibi, v. 350b

32 Üstübecin mermer üzerinde keskin sirke ile ezilmesi ve bir miktar zamk ilavesiyle elde edilen beyaz renkli mürekkeptir. Bk. Bahattin Yaman, "Türk Kitap Sanatlarında Mürekkep," Türkler Ansiklopedisi c.1 (Ankara: Yeni Türkiye Yayınları, 2002), 447-459. 


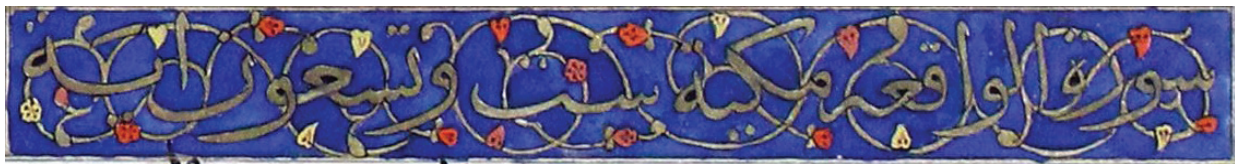

G. 14: Alanya Müzesi 487 numaralı Mushaf, Vâkıa sûresi sûrebaşı tezhibi, v. 358b

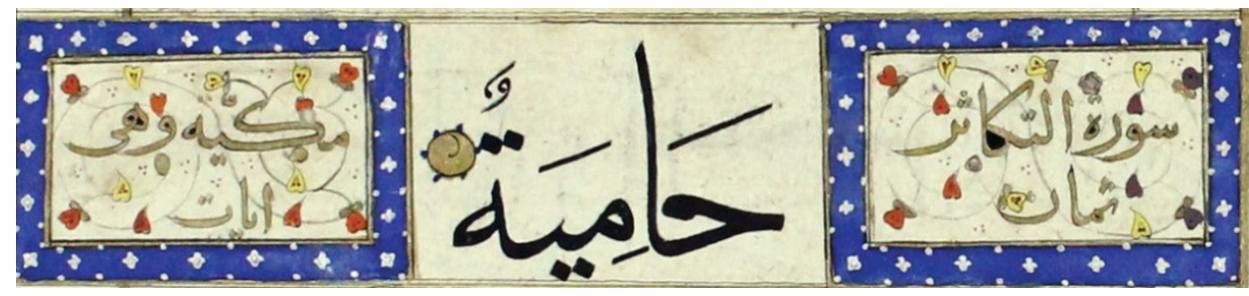

G. 15: Alanya Müzesi 487 numaralı Mushaf, Tekâsür sûresi sûrebaşı tezhibi, v. 408a

Yazı alanı paftalara ayrılmamış Karia (v. 407b) ve Tekâsür (v. 408a) sûrelerine ait sûrebaşlarında önceki sûrenin son kelimesi sûrebaşı yazısı alanının ortasına yazıldığı için, sûrebaşı yazısı ikiye bölünerek yazılmıştır. Dolayısıyla sûrebaşı bezemesi üçe bölünmüş ve iki kenarda kalan alan, koltuk tezhibi formunda tezyin edilmiştir (G. 15). A'râf (v. 99b) sûresinde de aynı durum söz konusu olmasına rağmen, bezeme ikiye bölünmemiştir. Sûrebaşında önceki sûrenin son kelimesi olan "Rahim" kelimesi, bezemenin ortasında siyah is mürekkebiyle yazılırken sûre bilgileri bu yazının iki tarafina pay edilerek beyaz üstübeç mürekkebiyle kaleme alınmıştır (G. 16).

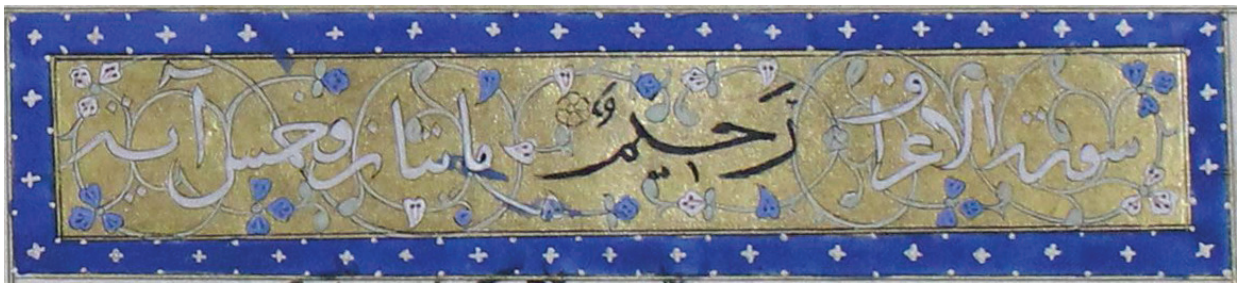

G. 16: Alanya Müzesi 487 numaralı Mushaf, A’raf sûresi sûrebaşı tezhibi, v. 99b

Yazı alanı, dendan veya rumî motifi ile ayrılan sûrebaşı bezemelerinin tamamında (doksan yedi adet) yazı alanının dişında kalan bölümde, 1/4 simetrik oranlı tasarımda, klasik tezhip tekniği kullanılmıştır. Desen tasarımında 1/4 simetrik oran kullanılmasına rağmen, hatayi grubu motiflerde renk kullanımında simetrinin göz ardı edildiği örnekler görülmektedir. Bu örneklerde yatay eksende motiflerin renk simetrisi korunurken, dikey eksende simetrinin kullanılmadığı tespit edilmiştir (G. 17). SK Hasan Hüsnü Paşa 1 ve TİEM 402 numaralı Mushaflar'da, yazı alanını ayırmada şemse formunun kullanılması, yazı alanı dışında 1/4 oranlı simetrik desen tasarımı (v. 262a), çalışmada ele alınan sûrebaşlarına benzerlik göstermektedir. 


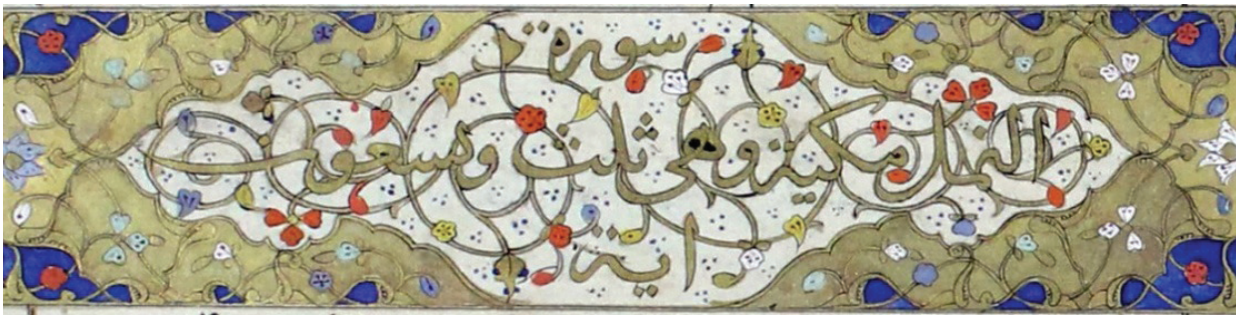

G. 17: Alanya Müzesi 487 numaralı Mushaf, Neml sûresi sûrebaşı tezhibi, v. 249a

Mushaf'ta yer alan sûrebaşlarında yazı zeminlerinde; kâğıt zemin, altın ve lacivert renk seçenekleri görülmektedir. Sûrebaşlarının kırk dokuz adedinde yazı zemin rengi altındır. Bunların kırk yedi adedinde, yazı altın üzerine beyaz üstübeç mürekkebi ile yazılmış ve harflerin etrafına siyah is mürekkebi ile tahrir çekilmiştir (G. 18). Geriye kalan iki adet yazı zemini altın olan Şems ve Kâfirûn sûresi sûrebaşında, yazılar zer-mürekkeple yazılmıştır (G. 19). Sûrebaşlarının otuz bir adedinde yazı alanı lacivert renklidir. Burada zer-mürekkeple kaleme alınan yazılara siyah is mürekkebi ile tahrir çekilmiştir (G. 20). Sûrebaşlarının otuz iki adedinde yazı alanında hiçbir renk kullanılmadan sûre bilgileri doğrudan yazı kâğıdının üzerine yazılmıştır (G. 21). Zer-mürekkeple kaleme alınan yazılarda harflerin kapalı formlu (göz) kısımlarının içi siyah ile doldurulmuştur (G. 17).

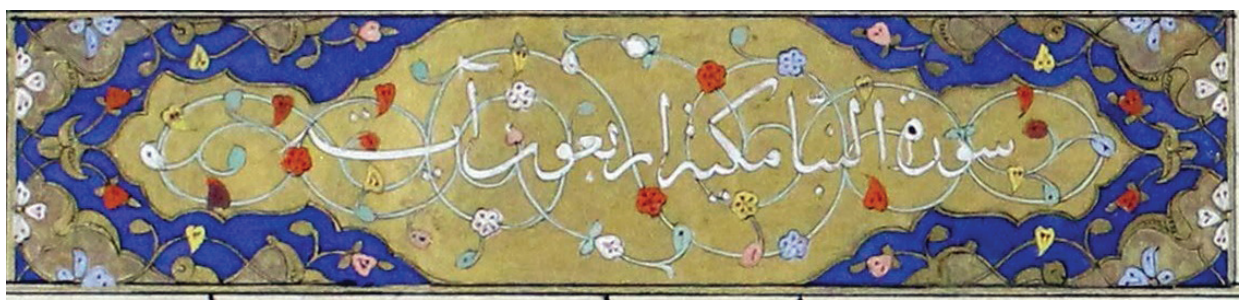

G. 18: Alanya Müzesi 487 numaralı Mushaf, Nebe sûresi sûrebaşı tezhibi, v. 394a

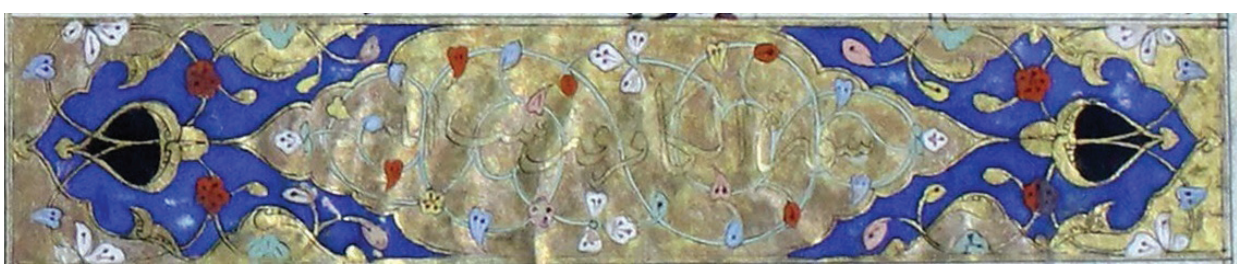

G. 19: Alanya Müzesi 487 numaralı Mushaf, Kâfirûn sûresi sûrebaş1 tezhibi, v. 409b 


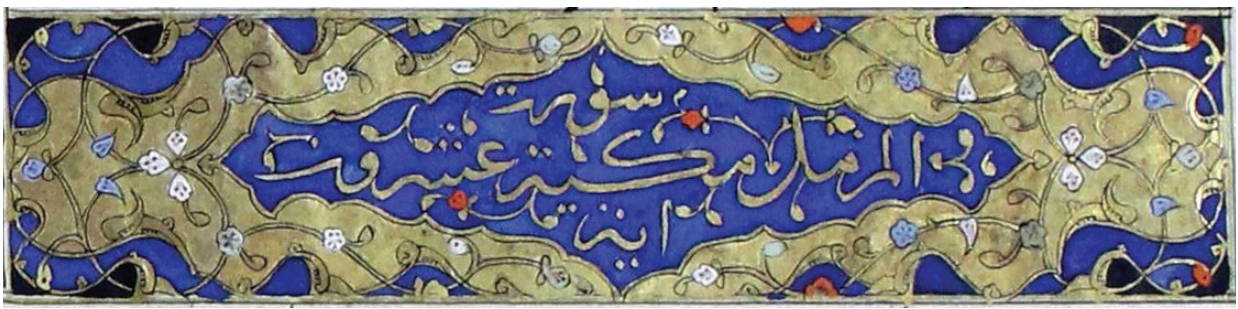

G. 20: Alanya Müzesi 487 numaralı Mushaf, Müzzemmil sûresi sûrebaş1 tezhibi, v. 387b

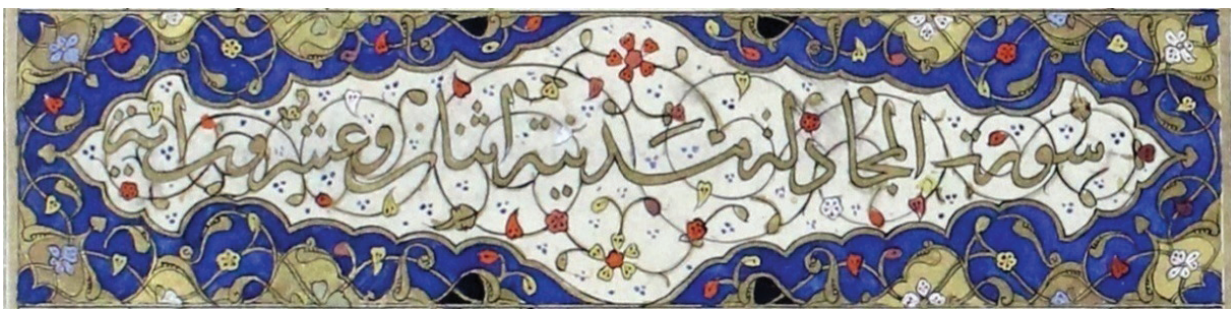

G. 21: Alanya Müzesi 487 numaralı Mushaf, Mücadele sûresi sûrebaşı tezhibi, v. 364a

Mushaf'taki sırasıyla sûrebaşları ele alındığında, sıralamada herhangi bir düzen veya kural tespit edilmemiştir. Ancak birbirini takip eden sûrebaşı tezhiplerinde, kâğıt-altın-lacivert zemin renklerinin sıralanmasında görülen, denge ve uyum dikkati çekmektedir.

İncelenen Kur'an-1 Kerîm'de sûrebaşı yazıları kaleme alınırken zer-mürekkep, beyaz üstübeç mürekkebi ve lacivert renkli mürekkep kullanılmıştır. Sûrebaşı yazılarının atmış üç adedi zer-mürekkeple (G. 22), kırk yedi adedi beyaz üstübeç mürekkebiyle (G. 23), iki adedi ise lacivert renkli mürekkep ile yazılmıştır (G. 24). Zer-mürekkep ile kaleme alınan sûrebaşı yazılarının otuz bir adedi lacivert zemine, otuz iki adedi ise kâğıt zemine yazılarak harflerin kenarlarına siyah is mürekkebi ile tahrir çekilmiştir. Yazımında beyaz üstübeç mürekkebi kullanılan sûrebaşlarında zemin, altın ile boyanmıştır. İki adet lacivert renkli yazıda (Târık ve Leyl sûresi) ise kâğıt zemin tercih edilmiştir.

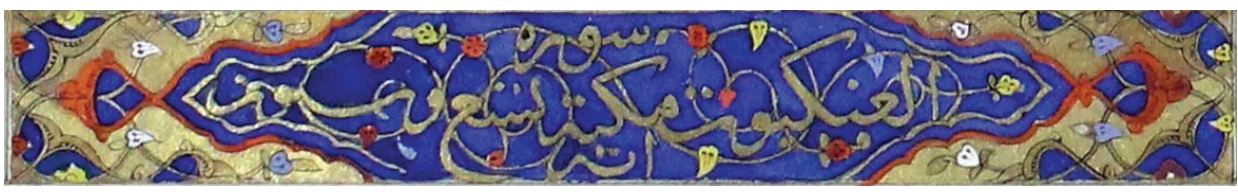

G. 22: Alanya Müzesi 487 numaralı Mushaf, Ankebût sûresi sûrebaşı tezhibi, v. 262a 


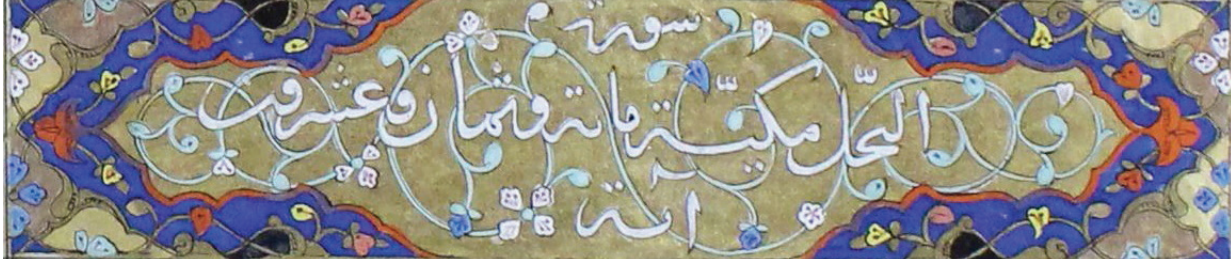

G. 23: Alanya Müzesi 487 numaralı Mushaf, Nahl sûresi sûrebaşı tezhibi, v. 172b

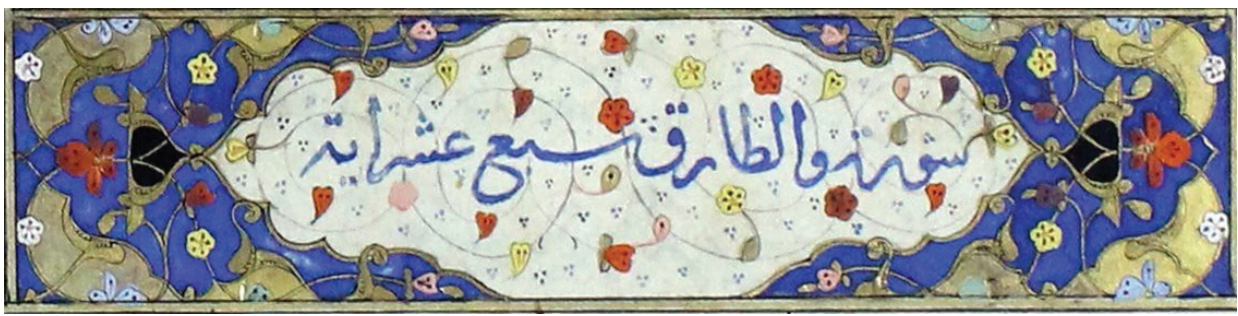

G. 24: Alanya Müzesi 487 numaralı Mushaf, Târık sûresi sûrebaşı tezhibi, v. 400b

Mushaf'ta tezhip sanatının belli başlı tekniklerinden olan klasik tezhip ve zerender-zer tekniklerinin kullanıldığı görülmüştür. Klasik renkli tarz tezhip tekniği; sap ve yapraklarda altın, çiçek ve zeminde renk kullanılarak uygulanır (G. 25, G. 26). İncelenen sûrebaşı tezhiplerinin tamamında klasik tezhip tekniği uygulanmıştır. Ancak yazı zemini kağıt olan bazı sûrebaşlarında, işçilikten kaynaklandığı düşünülen, yazı alnındaki dalların tek çizgi ile çizildiği örneklere de rastlanmıştır. Sûrebaşı bezemelerinde görülen bir diğer teknik ise iki renk altının bir arada veya tek renk altının mat, yarı parlak ve parlak kullanımıyla ortaya çıkan "altın içinde altın" olarak da isimlendirilen zer-ender-zer tekniğidir. ${ }^{33}$ Yazı alanı dışındaki bölümde, bu teknik altın zeminli paftalarda sıklıkla kullanılmıştır (G. 25).

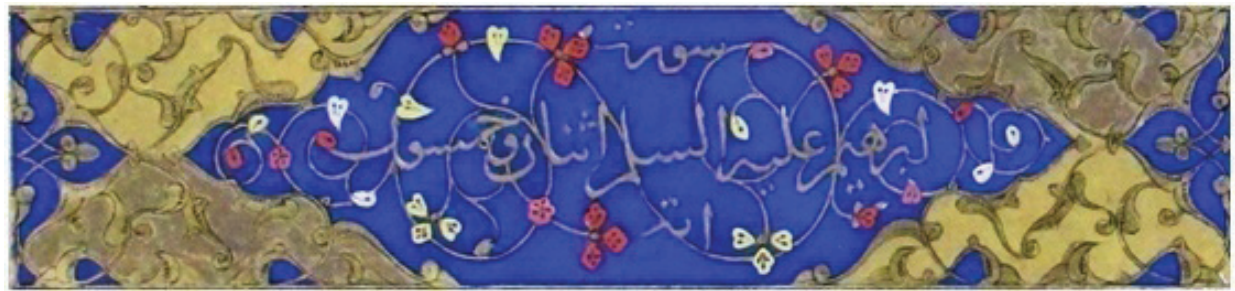

G. 25: İbrahîm sûresi sûrebaşı tezhibi, v. 164a, (Kaçar, 2020, 79)

33 Çiçek Derman, “Tezhip Sanatında Kullanılan Terimler, Tabirler ve Malzeme”, Hat ve Tezhip Sanatı, ed. Ali Rıza Özcan (Ankara: Kültür ve Turizm Bakanlığı Yayınları, 2015), 533. 
Sûrebaşlarında şemse formunda hazırlanan yazı zeminlerinde, zemine altın uygulamada, sıvama ve yapıştırma tekniklerinin her ikisinin de uygulandığı örnekler mevcuttur. Yazı alanı dışındaki bölümlerde görülen altın zeminli paftalarda ise sadece sıvama tekniğinin kullanıldığı görülmüştür.

İncelenen Mushaf'ın sûrebaşı tezhiplerinde; rumî, hatayi grubu, üç nokta, dendan, ve düğüm motifleri kullanılmıştır. Desen tasarımlarında genellikle rûmi ve hatayi grubu motifler birlikte yer almaktadırlar. Her bir sûrebaşında en az iki çeşit motif görülmüştür. Doksan altı adet şemsede yazının etrafına hatayi grubu motiflerle ( $\mathbf{G}$. 26), kalan bir adedi ise sadece rumî motifiyle tezyin edilmiştir (G. 27).

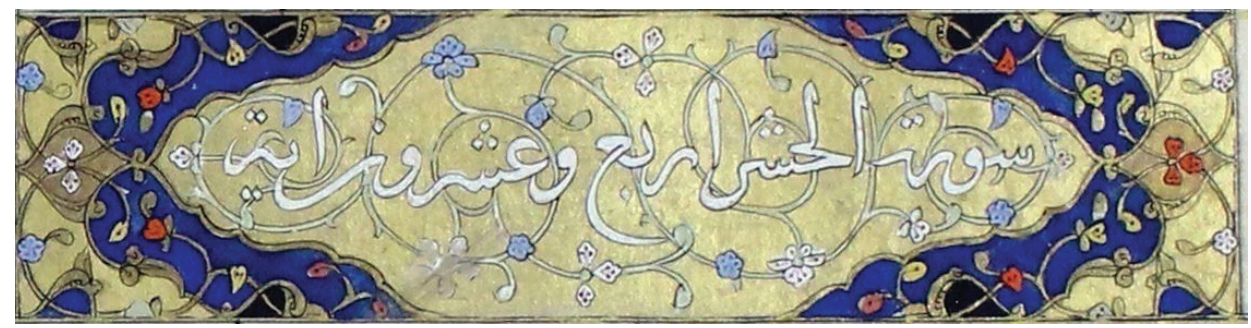

G. 26: Alanya Müzesi 487 numaralı Mushaf, Haşr sûresi sûrebaşı tezhibi, v. 366b

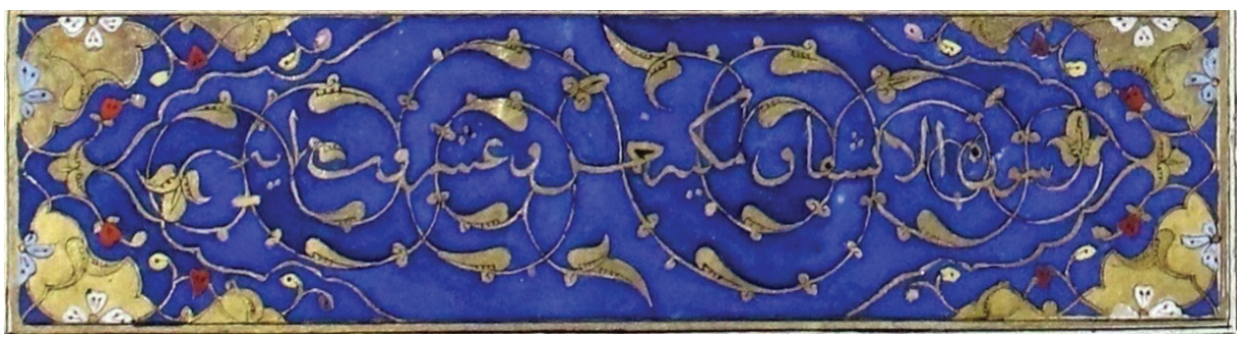

G. 27: Alanya Müzesi 487 numaralı Mushaf, İnşikâk sûresi sûrebaşı tezhibi, v. 399a

Sûrebaşlarının seksen beş adedinde yazı alanı dışında, desen tasarımında hatayi grubu motiflerle birlikte rumî motifinden yararlanılmıştır (G. 28). Dokuz adedinde sadece hatayi grubu motifleri (G. 29), üç adedinde ise sadece rumî motifi kullanılan tasarımlar mevcuttur (G. 30). 


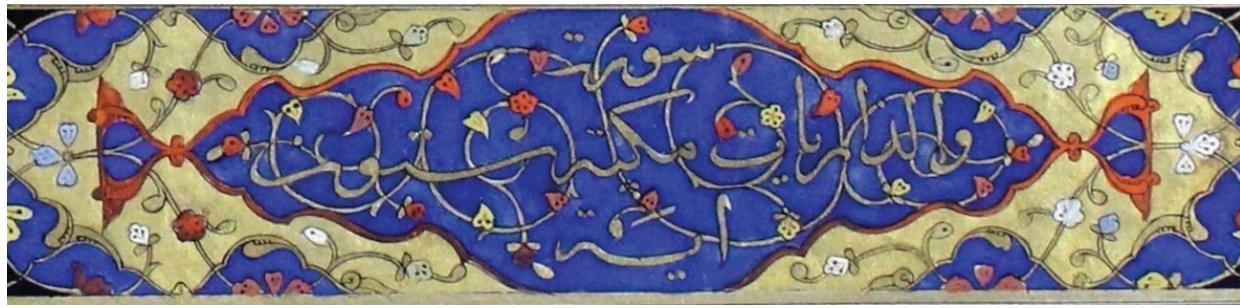

G. 28: Alanya Müzesi 487 numaralı Mushaf, Zariyât sûresi sûrebaşı tezhibi, v. 348b

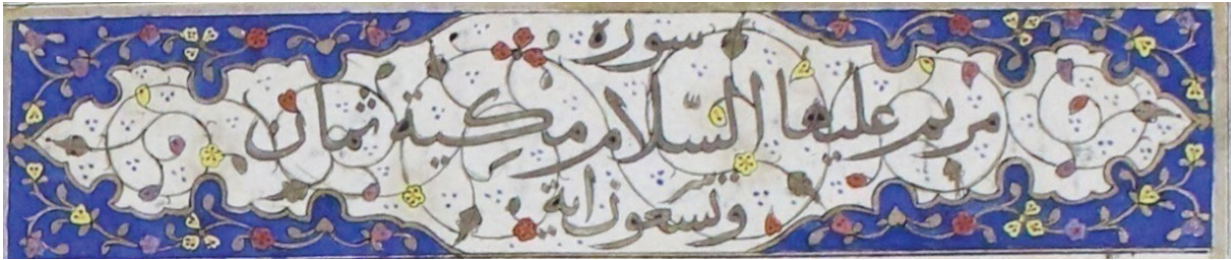

G. 29: Alanya Müzesi 487 numaralı Mushaf, Meryem sûresi sûrebaşı tezhibi, v. 199b

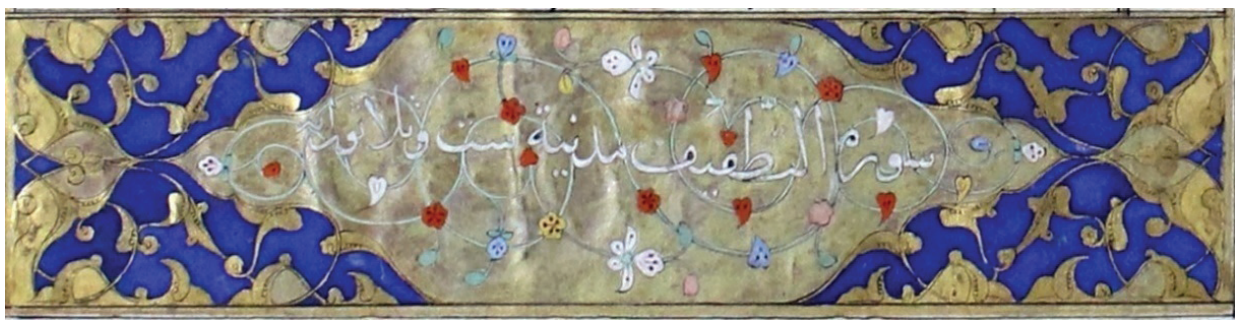

G. 30: Alanya Müzesi 487 numaralı Mushaf, Mutaffîfin sûresi sûrebaşı tezhibi, v. 398a

Yazı alanı paftalara ayrılmamış Rad, Duhan ve Kasas sûreleri sûrebaşında hatayi grubu motifler kullanılarak yazının etrafında, serbest desen tasarımı uygulanmıştır (G. 4). Diğer on iki adedinde ise yazının etrafındaki boşluklarda ters simetrik helezonik bitkisel hat üzerine goncagül, penç ve basit yaprak motifleri serbest olarak yerleştirilmiştir (G. 13, G. 14). Yazı alanının ayrıldığı sûrebaşlarında genellikle dış cetvelin alt ve üst kenarına bitişik, iç zemini siyah renkli, yarım ortabağ motifleri dikkati çekmektedir (G. 31). Ayrıca kâğıt zeminli yazı alanlarında serbest olarak yerleştirilmiş üç nokta (benek) motifi dikkati çekmekte, altın, siyah veya mavi renk seçenekleriyle uygulandığı görülmektedir (G. 21). ÜIKK A 6662 v. 444b, 439b'de cetvele bitişik s1ralanmış rûmi ortabağ ve kapalı formları zemin ayırmada kullanıldı̆̆ı görülmektedir. 


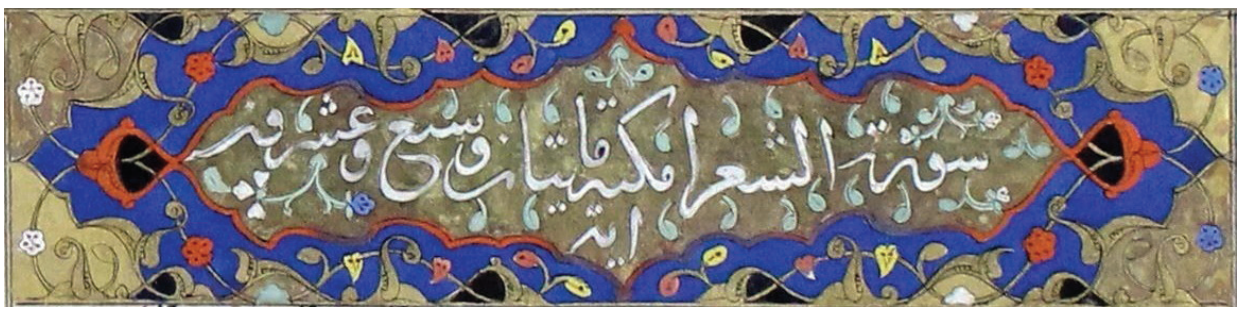

G. 31: Alanya Müzesi 487 numaralı Mushaf, Şuârâ sûresi sûrebaşı tezhibi, v. 241b

Hatayi grubu motiflerin büyüklügü, genellikle aynı veya birbirine yakın olmasına rağmen, bazı motifler diğerlerinin iki-üç katı büyüklüğünde olması dikkati çekmektedir. Üç yapraklı goncagül, dört veya beş yapraklı penç sıkça kullanılmış iri motiflerdendir. Bu motifler çift tahrir ${ }^{34}$ tekniğinde olduğu gibi, taç yaprakları birbirine değmeyecek şekilde çizilmiş ve kenarlarına tahrir çekilmiştir. Rûmi motifinin uygulamaları incelendiğinde; salbeklerde ve zemin rengi ayırma motifi olarak kullanılan kapalı form rûmilerin, diğer rûmi motiflere oranla daha büyük olduğu örneklere rastlanmaktadır. Ayrıca tepelik (rûmi motifi) formunun, bağlandığı motife nispetle daha büyük olduğu görülmüştür. Ayrıca dügüum motifinin, rûmi motif hattı üzerine yerleştirilen örneklerine rastlanmaktadır (G. 32).

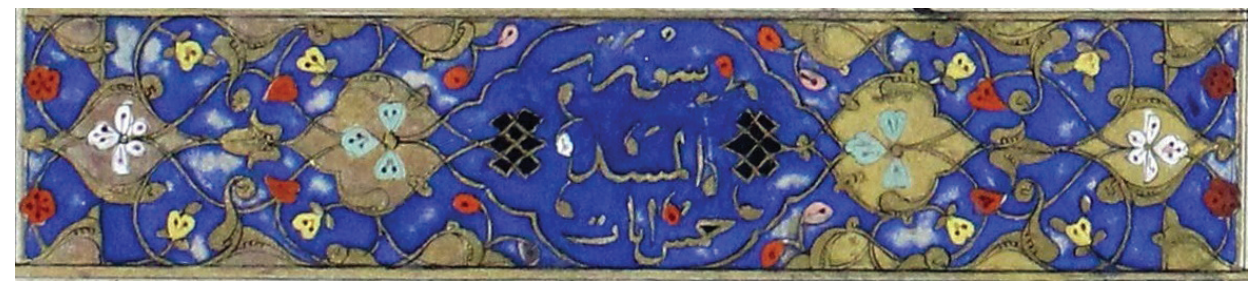

G. 32: Alanya Müzesi 487 numaralı Mushaf, Mesed (Tebbet) sûresi sûrebaşı tezhibi, v. 410a

Sûrebaşlarında motiflerde kullanılan renkler; mavi, sarı, beyaz, pembe, koyu ton kırmızı ve turuncudur. Mushaf'ın bütününde sûrebaşlarında kullanılan renklerin tonları aynı veya birbirine çok yakındır. Motifler tek ton renkle boyanmış ve üzerlerine siyahla küçük çizgisel detaylar işlenmiştir. Zemin boyamada ise altın ve lacivert rengin kullanıldığı görülmektedir. Ayrıca küçük zeminlerde ve ortabağ motifinin iç zeminlerinde siyah renk tercih edilmiştir. Zemin boyamada kullanılan lacivert rengin tonu, Mushaf'ın tamamında aynıdır. Bu durum aynı boyanın kullanıldığı fikrini oluşturmaktadır. Zemin boyamada altının parlak, mat ve yarı mat halinin kullanıldığı anlaşılmaktadır.

34 Tezhipte kullanılan boyama tekniğidir. Motifi oluşturan parçalar arasında tahrir kalınlığında boşluk bırakılarak uygulanır. Bundan dolayı "havalı" tabiri de kullanılır. Derman, "Tezhip Sanatında Kullanılan Terimler, Tabirler ve Malzeme," 526. 


\section{Sonuç}

Sûrebaşı tezhiplerinin hazırlanmasında esas olan, kompozisyon ve desen tasarımıdır. İşçilikte görülen incelik, titizlik, maharet gibi hususlar işin zanaat boyutunu sergilemektedir. Bir yazma eserin tezyinat gücünü ortaya koyan unsur, desendir. Desen hazırlama safhasında, ilk olarak kompozisyon tasarımı, ikinci sırada ise kullanılacak motiflerin seçimi ve büyüklüğünün belirlenmesi (uygulanacak tekniğge göre), önem arz etmektedir. Desen tasarımının temelini, bu iki husus oluşturmaktadır. Desende görülen motiflerin; formu, büyüklüğü, sıklığı, çeşitleri, denge, espas, vb. unsurlar üslupların karakteristik özelliklerini yansıtırlar. Bu özellikler aynı zamanda, istinsah tarihi belli olmayan yazma eserlerin dönem tahmininde kullanılan k1staslardandır.

Çalışmada, Konya Yazma Eserler Bölge Müdürlüğü’nde Korunan Alanya Müzesi 487 Envanter Numaralı Kur'an-1 Kerîm nüshasında, farklı yüz on iki adet sûrebaşı (başlık) tezhibi incelenmiştir. Bir yazma eserin tezyinatında kullanılan desenlerde, tekrara düşmeden, zengin çeşitliliğin nasıl oluşturulduğu konusuna 1şık tutmak adına çalışmaya yön verilmiştir. Sûrebaşı tezhipleri Mushaf'taki dizilişine göre sıralanarak incelenmiş ve kendi içlerinde uygulanmış olabilecek, düzen veya kural varlığı tespit edilmeye çalışılmıştır. Ayrıca çalışmada sûrebaşı tezhipleri kendi içerisinde ve birbiriyle mukayese edilerek detaylı olarak değerlendirilmiştir.

Sûrebaşı tezhipleri, sistematik bir incelemeye tabi tutularak değerlendirme yapılmıştır. Daha önce de ifade edildiği gibi; desen özellikleri, yazı zemin rengi, yazı rengi, teknik özellikler ile kullanılan motif ve renklere göre beş grupta değerlendirme yapılmıştır. Elde edilen sayısal verilere, tekrara düşmemek için burada yer verilmemiştir.

Sûrebaşları sayfadaki konumuna göre; sülüs, tek nesih veya iki nesih satır aralığına denk gelişine bağlı olarak, ölçüleri farklılık göstermektedir. Bu bağlamda sûrebaşı tezhip tasarımları kendi içinde mukayese edildiğinde, küçük alanda (tek nesih satır ölçüleri); yazı zemini şemse formuyla ayrılmış, daha ince, zengin tasarım ve işçiliğe sahip örnekler mevcut iken, daha geniş alanda (sülüs satır ölçüleri); yazı zemini ayrılmamış, daha sade ve yalın desen tasarımının kullanıldı̆̆ı örneklere de rastlanılmıştır. Bu durumda sûrebaşının desen tasarımında, alanın büyüklüğünün etkisinden ziyade, müzehhibin tasarım gücünün etkili olduğu söylenebilir.

İncelenen Mushaf'ta sûrebaşı tezhibi tasarımlarında görülen çeşitliliği oluşturmada; kompozisyon, yazı özellikleri, yazı zemin rengi, zemin ayırma motifi-formu, bezemede görülen üslup, teknik ve motiflerle sağlanması, eserin kurumsal bir ortamda hazırlandığı olasılığını akla getirmektedir. Bununla birlikte Mushaf'ta tasarımlar arasındaki uyum, denge ve sıralama dikkati çekmektedir. Ayrıca sûrebaşı tezhiplerinde farklı işçilikler de görülmüştür. Bu durum Mushaf'ın bezemesinin bir kişi tarafından değil de bir kişinin kontrolü altında birden fazla müzehhibin çalışmış olabileceği ihtimalini düşündürmektedir. Disiplinli bir çalışmayı gerektiren bu durum eserin nakkaşhanede 
veya nakkaşbaşı gibi bir otoritenin danışmanlığı altında yapılmış olabileceği düşüncesini desteklemektedir.

Rûmi motifinin bazı sûrebaşlarında, klasik üslupta olduğu gibi ince ve zarif uygulamaları yer almaktadır. Bununla beraber bazılarında ise, klasik dönem öncesinde görülen daha dolgun ve bodur formlar izlenmektedir. Bu durum da sûrebaşı tezyinatını farklı müzehhiplerin yapmış olabileceğini desteklemektedir. Sûrebaşı tezhiplerinde karşımıza çıkan, küçük zeminlerde (ortabağ iç zemini) siyah renk kullanımı ve dügüm motifi, Herat üslubunun etkileri görülen Fatih dönemi yazmalarını hatırlatmaktadır.

Eserin tamamında motiflerde kullanılan renklerin tonları aynı veya birbirine çok yakın olduğu tespit edilmiştir. Bu durum bütün sûrebaşlarının aynı yerde veya hazırlanan aynı boyaların farklı müzehhipler tarafından kullanılmış olabileceği ihtimalini desteklemektedir. Zemin boyamada kullanılan lacivert rengin tonu ise Mushaf' 1 n tamamında aynı olduğu gözlenmiştir. Bu da aynı boyanın kullanıldığı fikrini teyit etmektedir. Zemin renginde görülen dalgalanma ve değişimin sebepleri olarak, boyadaki su oranı veya işçilik olabileceği düşüncesi hâkimdir. Bunlarla birlikte saklama koşullarının etkisiyle oluşabilecek yıpranma ve bozulmalar da göz önünde bulundurulmalidir.

Tezyinatta altın zeminlerde paftalar arasında renk değişimleri görülmektedir. Zamana, kullanım ve saklama koşullarına bağlı yıpranma, uygulama tekniği, altının içindeki su veya yapıştırıcı (arap zamkı, jelatin) oranı dengesi gibi faktörlerin etkisi renk değişiminin sebepleri olarak sayılabilir. Yapılan yakından incelemede, kullanılan altında oksitlenme görülmemiştir. Yazı zemininde altın kullanılan sûrebaşlarının bazılarında ise yapıştırma altın kullanıldığı düşünülmektedir (Fecr Sûresi, v.402b).

Dehr (İnsan) sûresi (v. 391a) sûrebaşında yazı alanını belirleyen şemse formunda ve yazı alanı dışındaki motiflere tahrir çekilmediği tespit edilmiştir. Bu durumun sebepleri arasında; ilk olarak yıpranma veya tahribatın etkisi düşünülebilir. İlave olarak daha kuvvetli bir ihtimalle, tahrir çekme işleminin unutulması veya herhangi bir sebepten dolayı çekilememesi olabilir. Sûrebaşında altın zeminli şemseyi çevreleyen ince, parlak bir dendanın varlı̆̆ı, tahririn unutulması ihtimalini öne çıkarmaktadır. $\mathrm{Bu}$ bağlamda günümüzde klasik tezhip tekniği uygulamada, tezyinatta kullanılan bütün motiflerin kenarlarına tahrir çekildikten sonra zemin rengi girilmektedir. Oysaki burada tahrir olmamasına rağmen, zemin rengi mevcuttur. Bu durum Mushaf'ın bezendiği dönemde bu tür uygulamaların yapılıyor olabileceği ihtimalini de akla getirmektedir.

Çalışmada yapılan detaylı inceleme neticesinde sûrebaşı tezhiplerinin; desen tasarımı, altın ve lacivert rengin zemin boyamada kullanımındaki denge, şemse formu, altının; mat, yarı mat ve parlak halinin kullanılması, motiflerin üzerine yerleştirildiği helezonik hattın varlığı, motif formları, denge, espas, renkler ve teknik özellikle- 
ri, Osmanlı dönemi klasik üslup özelliklerini taşıdığını göstermektedir. Ancak bazı sûrebaşı tezhiplerinde, klasik dönem öncesi tezyinatına ait izlerin varlığı da göz ard1 edilmemelidir. Bunlarla birlikte sûrebaşlarının Mushaf içerisinde sıralanışına göre desen özellikleri açısından, kural veya düzen tespit edilememiştir. Bütün bunlarla birlikte görülüyor ki, bir yazma eserde tezyinatı oluşturan niceliksel unsurların sınırlı olmasına karşın, üretilen nitelik sınırsız ve özgündür.

Sonuç olarak; istinsah tarihi belli olmayan, elde edilen bulgulara dayanılarak yap1lan değerlendirmeye göre; bir nakkaşhane veya nakkaşbaşı danışmanlığında hazırlandığına inanılan ve Osmanlı dönemi klasik üslup özelliklerini içerisinde barındırdığı düşünülen eserin, tezhip sanatının kullanım alanlarından olan sûrebaşı teyzinatının örneklerini içermesi nedeniyle, bir kültür mirası olarak korunması, yazılı olarak kayı1 altına alınması ve gelecek nesillere aktarılması büyük önem arz etmektedir.

\footnotetext{
Hakem Değerlendirmesi: Dış bağımsız.

Çıkar Çatışması: Yazarlar çıkar çatışması bildirmemiştir.

Finansal Destek: Yazarlar bu çalışma için finansal destek almadığını beyan etmiştir.

Peer-review: Externally peer-reviewed.

Conflict of Interest: The authors have no conflict of interest to declare.

Grant Support: The authors declared that this study has received no financial support.
}

\section{Kaynakça/References}

Altıkulaç, Tayyar. Günümüze Ulaşan Mesâhif-I Kadime: İlk Mushaflar Üzerine Bir Inceleme. İstanbul: İslam Tarih, Sanat ve Kültür Araştırma Merkezi, 2015.

Arıtan, Ahmet Saim. "Ciltçilik.” İslam Ansiklopedisi. 7. İstanbul: Türkiye Diyanet Vakfı Yayınları, 1993, 551-557.

Aşıc1, Seher. "Fatih Devri Tezhip Üslubu.” Sanatta Yeterlilik Tezi, Marmara Üniversitesi, 2007.

Ayverdi, İlhan. Misalli Büyük Türkçe Sözlük. 1 cilt. İstanbul: Kubbealtı Yayınları, 2005.

Balkanal, Zeynep. "Bilgi ve Sanatı Kaplayan Sanat: Ciltçilik.” Türkler Ansiklopedisi. 12. Ankara: Yeni Türkiye Yayınları, 2002, 545-562.

Binark, İsmet. Eski Kitapçılık Sanatlarımız. Ankara: Kazan Türkleri Kültür ve Yardımlaşma Derneği Yayınlar1, 1975.

Birış1k, Abdülhamit. “Kur'an.” İslam Ansiklopedisi, 26. Ankara: Türkiye Diyanet Vakfı Yayınları, 2002, 383-388.

Birışık, Abdülhamit. "Sûre.” İslam Ansiklopedisi. 37. Ankara: Türkiye Diyanet Vakfı Yayınları, 2009, 538-539.

Birol, İnci A. ve F. Çiçek Derman. Türk Tezyini Sanatlarında Motifler. İstanbul: Kubbealtı Neşriyatı, 2011.

Birol, İnci A. Klasik Devir Türk Tezyîn̂̂ Sanatlarında Desen Tasarımı. İstanbul: Kubbealtı Neşriyat, 2009.

Celasin, Ayşe Tanrıver. "XV.-XIV. Yüzyıl Osmanlı Tezhip Sanatı Bağlamında Şeyh Hamdullah 
Mushafları Sûrebaşı Bezemelerinin Değerlendirilmesi." Doktora Tezi, Süleyman Demirel Üniversitesi, 2014.

Celasin, Ayşe Tanrıver. “Tezhip Sanatında Emevî Dönemi Sûrebaşı Bezemelerinin Yeri.” Art-e Sanat Dergisi 6 (2013): 120-138. https://dergipark.org.tr/en/pub/sduarte/issue/20732/221567

Çı̆̆g, Kemal. Türk Kitap Kapları. İstanbul: Yapı ve Kredi Bankası Yayınları, 1971.

Derman, Çiçek. “Tarihimizde Mushafların Bezenmesi.” Diyanet İlmi Dergi 46/4 (2010): 137-144.

Derman, F. Çiçek. “'Osmanlı' da Klasik Dönem Kanûnî Sultan Süleyman (1520-1566) Türk Tezhip Sanatının Muhteşem Çağı: 16. Yüzyıl.” Hat ve Tezhip Sanatı. Ed. Ali Rıza Özcan. Ankara: Kültür ve Turizm Bakanlığı Yayınları, 2015, 343-359.

Derman, F. Çiçek. "Tezhip Sanatında Kullanılan Terimler, Tabirler ve Malzeme.” Hat ve Tezhip Sanatı. Ed. Ali Rıza Özcan. Ankara: Kültür ve Turizm Bakanlığı Yayınları, 2015, 525-534.

Duran, Gülnur. “Tezhip,” İslam Ansiklopedisi. 36. İstanbul: Türkiye Diyanet Vakfi Yayınları, 2009, 567-569.

Duran, Gülnur. “Tezhip Sanatının Kullanım Alanları.” İslam Ansiklopedisi. 41. İstanbul: Türkiye Diyanet Vakfı Yayınları, 2012, 63-65.

Ersoy, Ayla. Türk Tezhip Sanatı. İstanbul: Akbank Yayınları, 1988.

Gündüz, Hüseyin. "Türk Hat Sanatında Şeyh Hamdullah ve Ahmed Karahisârî.” Hat ve Tezhip Sanatı. Ed. Ali Rıza Özcan. Ankara: Kültür ve Turizm Bakanlığı Yayınları, 2015, 75-87.

Kaçar, Ummuhan. “Konya Yazma Eserler Bölge Müdürlüğ̈̈nde Korunan Alanya Müzesi 487 Envanter Numaralı Kur'an-1 Kerîm'in Tezhiplerinin İncelenmesi.” Yüksek Lisans Tezi, Kastamonu Üniversitesi, 2020.

Keskiner, Cahide. Türk Süsleme Sanatlarında Stilize Çiçekler Hatayi. Ankara: Kültür Bakanlığı Yayınları, 2002.

Kurfeyz, Nilüfer. Tezhip. İstanbul: Tatav Yayınları, 2003.

Küpeli, Gülnihal. “Tezhip Sanatında Yenilik Arayışları: II. Bayezid Dönemi (1481-1512).” Hat ve Tezhip Sanatı. Ed. Ali Rıza Özcan. Ankara: Kültür ve Turizm Bakanlığı Yayınları, 2015, 321-341.

Mahir, Banu. “Topkap1 Saray Kütüphanesi’nin Kur'an Koleksiyonu.” Türkiyemiz Kültür ve Sanat Dergisi 22/67 (İstanbul: Akbank Yayınlar1, 1992): 16-27.

Mahir, Banu. "Osmanlı Bezeme Sanatlarında Saz Üslubu.” Hat ve Tezhip Sanatı. Ed. Ali Riza Özcan. Ankara: Kültür ve Turizm Bakanlığı Yayınları, 2015, 379-95.

Memiş, Mehmet. “Türk Hat Sanatında Hz. Muhammed Sevgisini Konu Alan Çalışmalar.” Art-Sanat 14 (Temmuz 2020): 242-272. https://dergipark.org.tr/tr/download/article-file/1233425.

Mesara, Gülbin. “Kanuni Sultan Süleyman'ın Sernekkaşı Karamemi.” Hat ve Tezhip Sanatı. Ed. Ali Rıza Özcan. Ankara: Kültür ve Turizm Bakanlığı Yayınları, 2015, 361-77.

Özcan, Yılmaz. Türk Kitap Kaplarında Şemse Motifi. Ankara: Kültür Bakanlığı Yayınları, 1990.

Özen, Mine Esiner. Türk Cilt Sanatı. Ankara: Türkiye İş Bankası Kültür Yayınları, 1998.

Özönder, Hasan. Ansiklopedik Hat ve Tezhip Sanatları Deyimleri, Terimleri Sözlügü̈. Konya: Sebat Ofset, 2003.

Serin, Muhittin. "Yakut El Musta'sımî.” İslam Ansiklopedisi. 43. İstanbul: Türkiye Diyanet Vakfı Yayınlar1, 2013, 291-293.

Ünver, Süheyl. “İstanbul’un Fethinden Sonra İlim ve Sanat.” Fethin 511. Yıldönümü Konferansları. İstanbul: İstanbul Üniversitesi Yayınları, 1964, 16-28. 
Sümbüllü, Y. Ziya. “İlm-i Tefe'ül ve Tefe'ül-Name (Kur'an Falı) Üzerine Bir Değerlendirme.” Uluslararası Sosyal Araştırmalar Dergisi 1/2, (Kış 2008): 383-391.

http://www.sosyalarastirmalar.com/cilt1/sayi2/sayi2pdf/sumbullu_yusuf_ziya.pdf.

Tanınd1, Zeren. "Kur'an-1 Kerim Nüshalarının Ciltleri ve Tezhipleri." 1400. Yılında Kur'an-ı Kerim, Türk ve İslam Eserleri Müzesi Kuranı Kerim Koleksiyonu. Ed. Müjde Unustası. İstanbul: Antik A.Ş., 2010, 90-121.

Tanınd1, Zeren. “Başlangıcından Osmanlı’ya Tezhip Sanatı.” Hat ve Tezhip Sanatı. Ed. Ali Rıza Özcan. Ankara: Kültür ve Turizm Bakanlığı Yayınları, 2015, 243-281.

Taşkale, Faruk. “Tezhip Sanatının Kullanım Alanları.” Yüksek Lisans Tezi, Mimar Sinan Güzel Sanatlar Üniversitesi, 1994.

Yaman, Bahattin. “Türk Kitap Sanatlarında Mürekkep.” Türkler Ansiklopedisi. 12. Ankara: Yeni Türkiye Yayınları, 2002, 447-459. 